Elze Matulionyte

\title{
Transatlantic GMO Dispute in the WTO: Will Europe further abstain from Frankenstein Foods?
}


Das Europainstitut der Universität Basel ist ein rechts-, politik- und wirtschaftswissenschaftliches Zentrum für interdisziplinäre Lehre und Forschung zu europäischen Fragen. Neben einem einjährigen, praxisbezogenen und interdisziplinären Nachdiplomstudium zum Master of Advanced European Studies und dem Vertiefungsstudium Major in Conflict and Development werden spezielle Weiterbildungskurse angeboten. In der Forschung werden in Zusammenarbeit mit benachbarten Instituten sowohl fachspezifische wie multidisziplinäre Themen bearbeitet. Das Europainstitut ist als Ansprechpartner für Politik, Wirtschaft und Verwaltung beratend tätig.

Elze Matulionyte graduated as Master of Advanced European Studies at Europainstitut of Basle University in October 2004. This article is based on her master thesis of the postgraduate programme at Europainstitut. The thesis was carried out under the supervision of Dr. Christa Tobler, LLM and Dr. Krista Nadakavukaren-Schefer, to whom the author expresses her deepest gratitude. Since the graduation of MAES in October 2004 in Basel she works as a head of division at European Law Department under Lithuanian Ministry of Justice, Vilnius, Lithuania. She is also a PhD student at European Law Department, Faculty of Law, Vilnius University, and teaching associate of EuroFaculty Vilnius. 


\section{Content}

INTRODUCTION

PART ONE. THE DISPUTE

PART TWO. EC BIOTECHNOLOGY REGULATION:

LAW, IMPLEMENTATION AND EFFICIENCY

2.1. (Non)-implementation of the regulatory framwork within the EU

2.2. WTO challange - an impetus for a change

3.1. Moratorium and GATT: national treatement, likeness and exception

3.2. Autorisation of GMO and the SPS Agreement 3.2.1. Mesures allowed under the SPS Agreement 22 3.2.2. GMO regulation as a SPS measure: international standards, risk assesment, precaution

3.2.3. Precautionary principle

3.3. The change in the EU regime and the TBT Agrement 32 
PART FOUR. DISPUTE SETTLEMENT PROCEDURE IS LAUNCHED... AND SO WHAT?

4.1. Is the WTO a proper forum for biotech isssues? 36 4.1.1. Opening the WTO to non-economic issues $\quad 37$ 4.1.2. Possibiliy of negitiated settlement

4.2. Will the EU enforce a negative decision?

4.3. An Alternative: conditional admittance of GMOs 


\section{INTRODUCTION}

What do Frankenstein and Geneva have in common? The connection extends beyond the fact that Mary Shelley conceived her novel about new Prometheus (or Frankenstein) when staying on the bank of Lake Geneva in Switzerland, but also to the fact that honourable members of the WTO dispute settlement bodies, sitting on the bank of the same lake, will judge (or, in WTO jargon, will 'adopt a report') on the issue of authorisation of genetically modified organisms, quite often referred in Europe as 'Frankenstein foods'.

Biotechnology has been recently becoming a focal point of European policy makers, as it is assumed that the growth of the sector should have a great potential to contribute to economic growth. While Europe has been recently performing rather sluggish, the Commission grasped promotion of biotechnology as the last measure to improve 'Europe's competitiveness'. And all this ado is to attain its hardly achievable Lisbon agenda's goal 'to make Europe the most competitive, knowledge based economy until $2010^{\prime} .1$ Besides dubious feasibility of the general great goal it should be noted that the chances of GMO making the decisive influence are rather slim, partly because of the hostile reaction towards them by the European public. Several recent food related scandals (such as BSE, dioxins and foot and mouth disease) have shattered consumer trust in the safety of the food supply. As concerns over the industrialization of food production intensifies, reluctance to accept more technology in food production becomes more apparent. ${ }^{2}$

Ever since the modern biotechnology has been developed, the EC took more careful regulatory approach. Legal framework became even more rigid as the public distrust in GM products was rising. The US, on the contrary, has largely adopted biotechnology in agriculture. Thus differences of regulation and acceptance of GMOs between the US and the EU has led to trade difficulty in particular for US exporters 
since more GM corn varieties have been authorised within the US than in the EU. These differences could be attributed simply to placative European cautiousness, or explained by more significant societal dissimilarities, traced back even to the political economy considerations. ${ }^{3}$ The fact that non-acceptance of the GMO's to the European markets impedes development of the biotechnology in Europe (and perhaps a more rapid growth of the EU economy) is unfortunately only the inner side of the issue. The external side is that the EU, being a player in the international trade order, gets into probably never-ending disputes with its trade partners.

The area of controversies related to GMO issues is ample enough to write books on it. The scope of this paper is limited, however, to the particular aspects of the problem (for example, medical uses of GMOs are completely excluded). The paper analyses the clash between two multilevel governing systems - the EU and the WTO - on the regulation of GMOs' authorisation and seeks to answer a question whether a workable solution can be found through existing dispute settlement procedures. In particular, the debate concentrates on the usage of GMO in food products, in that way putting more emphasis on human health as underlying justification for restrictive European policies on GMOs. The paper is mainly based on the legal analysis of both - EU and WTO - regulatory mechanisms. However, in the area of the regulation of GMO the demarcation between law, politics, economics and 'science' is generally rather blurry. Intrinsic political and economical problems standing behind the legal framework of GMOs thus may not be ignored. Although the main emphasis rests with the study of the legal framework, the paper also seeks to present an interdisciplinary analysis of the dispute on GMO and its possible outcome (within the WTO or also out of its scope).

In the first part of the paper the development of the dispute will be introduced together with a brief history of the events. The emphasis is 
put only on the most recent events that followed the US complaint in the WTO. The second part depicts and gives an analysis of the main EU legislation in the field of biotechnology and its implementation, which caused this WTO dispute. The analysis concentrates not on the formal deficiencies of implementation by the Member States, but rather on the systematic failure of the regime and governance of complex issues in general. The most recent legislation, designed to cure the inefficient old regime, is also analysed. In the third part EU legislation and its actual performance are evaluated in the light of obligations stemming from the international trade law. Main problems caused both by the former moratorium on GMOs (such like the precautionary principle or 'likeness' of GMO products to their conventional counterparts) and by the new EU regime (in particular, rigid labelling and traceability requirements) are analysed here. The fourth part seeks to answer whether the WTO is a proper forum for this dispute because of its insensitivity for numerous non-economic issues, which are at stake in this case. Further on in the fourth part possible outcomes of the dispute are modelled - including the most pessimistic ones (e.g. non-implementation of the negative WTO solution or repeated WTO claims) and a more constructive one, which would entail concessions from both sides (namely acceptance of the GMOs for food use by the EU as well as acknowledgment of EU's rigid post-market measures by its trade partners).

\section{PART ONE. THE DISPUTE}

The challenge by the US of the EU's biotech products regime did not emerged in the WTO unexpectedly, as the dispute over authorisation of GMOs came out gradually. Most US exporters have stopped exporting corn (except soybean) to the EU already since 1999 and a special joint EU-US working group on biotechnology was created at that time. Although that working group aimed to monitor the progress of the dialogue on technical issues and to increase scientific and 
regulatory co-operation, its functioning was stalled since $2001 .{ }^{4}$ Since October 1998, for more than five and a half years, no new authorisations for placing GM products on the EC market were granted to either European or foreign firms. Moreover, abundant national safeguard measures concerning the GM products that were already authorised at the EU level were put in place. Even though the Commission was perfectly aware of the restrictive measures by Member States, no formal decision was taken in this relation. ${ }^{5}$ On 13 May 2003, the US (backed by Canada and Argentina) requested WTO consultations with the EC on an alleged standstill of approval of new GMOs and on national measures suspending the use and sale of approved GM products. Importantly, the US challenged de facto moratorium of GM products authorisation and not the formal regulatory regime. US claim consists of mainly two pleas: (1) the suspension by the EC of consideration of applications for, or granting of, approval of biotech products; (2) national marketing and import bans maintained by the Member States. ${ }^{6}$ Thus the focus of the initial WTO complaint is neither the EU legislation on GMOs and GM food approval as such, nor the recently adopted legislation on traceability and labelling of GMO in food so far, but rather the Community's alleged inaction on GMO issues. ${ }^{7}$

As one could have predicted the EU considered the US request as 'unhelpful both to us and to them'. ${ }^{8}$ The Commission argued initially that an official complaint was inappropriate given that the 'moratorium' had no formal status, but has more recently focused on restarting GMO approvals. Although the Commission still regards the WTO challenge as 'an inappropriate and regrettable move' it committed sequence of actions to make at least the actions of institutions look like 'GMO regulation mechanism compatible'. It has not only actively submitted proposals aimed at finishing the new framework regulation of $\mathrm{GMO}$, but also made attempts to ensure that ongoing authorisation procedures would move forward without delays. 
In parallel to the 'improvement' actions undertaken by the Commission runs the WTO dispute procedure. The Panel was established back in August 2003. However, in the absence of the agreement of the parties to the dispute, the composition was confirmed only in March 2004. Though awaited for the beginning of September 2004, the Panel's report will likely be issued only in June 2005, because of the complexity of process. ${ }^{10}$ Thus the dispute is now in progress, the decision is not yet clear and it is even more challenging to try to predict it and to observe and analyse the actions of the actors involved. The actions of the EU (of the Commission as well as the Member States) as the 'defending' party are especially interesting to analyse. For example, in addition to the above-mentioned changes in the Commission's approach towards GMOs approvals, the most important 'qualitative' move towards lifting of the moratorium was recent authorisation to place the first genetically modified product ${ }^{11}$ on the EU market since October 1998.

When the Commission authorised the import into the EU of sweet corn made from Syngenta's (although not the EU, but still 'Europebased' firm!) GM maize on 19 May 2004, it has finally brought to an end the EU's de facto moratorium. However, this approval resulted in even more controversy to the issue. On the one hand it was publicly condemned by consumer and environmentalist organisations. Such strong opposition of the public opinion even forced the company to announce immediately that it is not going to put the product on the market. ${ }^{12}$ On the other hand biotech industries consider this approval to be only the first step on the road to unblocking the approval process. Also the US did not seem to buy it. It seems that the applicants need more than one authorisation of a GM product to prove EC's seriousness over getting the system moving smoothly and efficiently ${ }^{13}$. Finally, the credibility of the decision is somehow penetrated with the feeling that it was the last try by the Commission to supply itself with some supporting 
evidence in the dispute and to timely submit it to the WTO, as the deadline for party submissions was only a few days later. ${ }^{14}$ It seemed that the Commission simply wanted to demonstrate to both - the trade partners and the European public - (and to both for different reasons) that the system of authorisation was working as designed. Only after the second approval of another genetically modified maize, known as NK603, in the end of July ${ }^{15}$, Commission's commitment to re-launch the mechanism of GMO approval gained more credibility and those who doubted that the moratorium would be lifted were left with less arguments. Meanwhile the Member States are taking steps to make use of any available power they retain under Community legislation to bring into force the most restrictive policy possible in relation to GM crops. ${ }^{16}$

\section{PART TWO. EC BIOTECHNOLOGY REGULATION: LAW, IMPLEMENTATION AND EFFICIENCY}

EU legislation on GMOs has been in place since the early 1990s. Ever since critics attack it as suboptimal, unworkable and inefficient (in addition to as trade restrictive) ${ }^{17}$ Until late 2002, the main piece of legislation, which governed procedure to place GMOs on the EU market, was Directive $90 / 220 / E E C^{18}$, which was then repealed by the new Directive 2001/18/EC on the deliberate release of GMOs. ${ }^{19}$ At the time when the new directive was put in place the old regime was not functioning properly and the GMO authorization process has already been stalled.

Under the old regime there was no independent scientific body at the Community level to evaluate the safety of GMO foods and the Commission exercised discretion on whether to consult scientific advisers. After major 'food hysterias' of late 90 s and incapability to effectively cope with them at the EU-level the regulatory framework of 
GMO had lost public credibility and legitimacy. In fact, European GMO governance has fallen into disrepute even earlier, when despite public opposition the Commission approved the first GM products. Thus the old regulation did not work because of both: the inefficiencies in the text (e.g. safeguard clauses or the abandoned 'simplified procedure' for substantially equivalent products) and the public opinion (general opposition to technology in food processing). In order to restore confidence, GMO regulation had to be submitted to comprehensive restructuring. In addition the background principle of precaution has further evolved by the time when the revised legislative framework was adopted. ${ }^{20}$

The revised Directive 2001/18/EC has introduced more stringent rules as compared to the old ones on the release of GMOs into the environment. In particular, it introduced principles of environmental/ health risk assessment (for which national responsible agencies or national competent authorities are responsible together with the newly created independent scientific body - European Food Safety Authority). Moreover, Member States are now obliged to ensure labelling and traceability of GMOs at all stages of the placing on the market and informing the public during approval procedure is made mandatory. In addition, first approvals for the release of GMOs are limited to a maximum of ten years. The adoption of this directive however did not immediately improve the functioning of the authorisation system and did not prevent the US to take the dispute to the WTO, as the pending applications for approvals further remained pending.

Shortly after the WTO dispute was initiated a new package, completing the regulatory framework of GMOs, was adopted. The completed package includes two important regulations, the first one on GM food and feed and the second one on traceability and labelling of GMOs. ${ }^{21}$ The updated regulatory framework is now based on the 'one door-one 
key' principle. This should mean that one can file a single application for obtaining both the authorisation for the deliberate release of a GMO into the environment (under Directive 2001/18/EC) and the authorisation for use of this GMO in food and (under Regulation 1829/2003) (See bellow, Scheme I). Accordingly, business operators are not required anymore to perform separate risk assessments for the use of the GMO in general, and for its use in food. Hence placing GMOs on the market and placing them on the market as food have merged in this sense.

\section{GMO Authorisation for use in food products}

The relative simplification of the authorisation procedure (Scheme 1 , p. 13) is well outweighed by the new labelling/traceability requirements (Regulation 1830/2003). They provide not only for an obligation to present comprehensive information on the labels of all food containing, consisting of or produced from a GMO, but also require to set up a hardly practicable 'traceability' system. Traceability is understood as the possibility to trace products throughout the whole production and distribution line (from selling a GM seed to a 'producer' to a final placing of a ready food product on the market). More precisely the requirement to assure traceability requires the involved undertakings to inform the next operator in the chain that the product is produced from $\mathrm{GMO}(\mathrm{s})$. Moreover, they are required to have systems for identification to whom GM products were provided or from whom they were acquired and such information must be retained and on demand made available to competent authorities for a period of five years. ${ }^{22}$ 


\section{Scheme I: Authorisation procedure}

\begin{tabular}{|l|l|}
$\begin{array}{l}\text { Applicant submits an application } \\
\text { to a competent national authority } \\
\text { of a Member State, in which the } \\
\text { product is to be marketed first. It is } \\
\text { possible to file a single } \\
\text { application: for food or feed use } \\
\text { (Reg } 1829 / 2003 \text { ) and for deliberate } \\
\text { release of a GMO into the } \\
\text { environment (Dir 2001/18). }\end{array}$ \\
\cline { 2 - 3 }
\end{tabular}

EFSA carries out risk assessment in accordance with the precautionary principle.

EFSA forwards its opinion on approval to the Commission within six months (can be extended) after receipt of application.

Preparing opinion EFSA:

1. may ask food assessment body of a MS to carry out safety assessment. 2. may carry out environmental risk assessment.

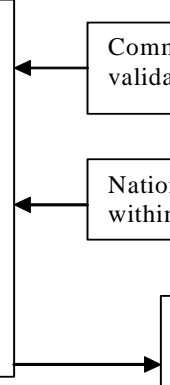

Authorisation decision is to be taken through regulatory committee procedure:

The Commission submits within three months a draft decision to the Regulatory Committee

The Regulatory Committee decides on

Ethical implications of biotechnology may be considered on initiative of the Commission or upon request of the Parliament. the matter is referred to the Council.

If the Council fails to take a decision within three months, the Commission takes a decision itself.

Following the placing on market of a GMO, the applicant must carry out monitoring, as specified in the approval, and submit reports to the Commission and Member States.

Labelling, packaging and traceability requirements must be complied with.

Applicant may place product on the market, where such decision is taken.

When authorisation period ( $\max 10$ years) expires, renewal procedure must be launched, analysing monitoring results, newly available information etc. 


\section{1. (Non)-implementation of the regulatory framework within the}

EU

Normally implementation of the Community law by the Member States would not be a relevant issue analysing compatibility of $E C$ regulations with international trade rules. However, in this particular GMO dispute the WTO Panel is called upon to decide on de facto moratorium, which was caused, among other factors, also by the actions of the Member States. One of the pleas in the dispute was exactly on national marketing and import bans that were maintained allegedly contrary to the EC law. That came about in the late 90 s when a number of Member States, following the growing public opposition to the GMO and reactions to mismanagement of health and food safety scares (such as the BSE crisis), have employed a possibility to invoke safeguard measures to the GM products already authorised at the EC level. ${ }^{23}$ More importantly, no formal decision from the Commission was taken in relation to these national safeguard measures, whereas the Commission was properly informed of them in most of the cases. ${ }^{24}$

While the Commission was compelled to accept joint opposition of the Member States, the legality of such national safeguard measures, was indirectly tested by the ECJ in Monsanto judgement. ${ }^{25}$ The judgement of the Court, being traditionally ambiguous in setting boundaries for 'domestic measures', allows for the interpretation that Member States may uphold their bans on GMOs at least as long as they are justified on risks for human health. ${ }^{26}$ The most important questions on the limits of risk assessment, on acceptability of precautionary measures, when the scientific evidence is non-existent, remained only partially answered.

It should be remembered that the above mentioned actions were based on the old regulatory regime, which was gradually changed. The Directive 2001/18 and even the most recent legislation that should have 
lifted the 'moratorium' do not seem to have an effect on national safeguard measures. Moreover, in the EU15 only seven Member States have fully communicated their implementation measures for Directive 2001/18/EC. ${ }^{27}$ At the end of the day the non-implementation by the other eight (old) Member States was referred to the ECJ. ${ }^{28}$

It is obvious that proper functioning of the common GM legislation was endangered mainly by two deficiencies of the Member States: (1) misuse of the safeguard measures and (2) non-implementation of the most recent legislation. The Commission could have launched infringement procedures against the national safeguard measures long ago, however, it decided to attack a formal 'non-implementation' of the new directive first.

\subsection{WTO challenge - an impetus for a change?}

The moratorium on the functioning of the GMOs regulatory regime was a clear indication that EU policy-making in this domain was inefficient due to both: the lack of legitimacy of EU GMO regulatory procedures and policy effectiveness. From the point of view of political science Member States' non-compliance with the EU-level regulation of GMOs provide evidence of the EU's weakened legitimacy in 'complex decisionmaking', and the inadequacy and insufficiency of output legitimacy in particular. Consequently, the recent initiatives to restore EU GMO regulatory authority through new, more effective regulation affirmed the importance of both input and output legitimation measures. ${ }^{29}$

The core problem of the policy on GMOs, however, stems from the fact that it is intrinsically facing a problem of achieving several conflicting goals at the same time. Firstly, it aims at fostering biotechnology, as the 'key growth technology' in Europe. Secondly, it seeks at the same time to assure the highest possible 'safety' of GMOs in order to satisfy public anxiety. Lastly, it must not restrict trade or at least not to appear 
so. The cleavage among the goals is mirrored in the lack of consistency of Commission's actions, as its services were seeing GMO related solutions from the very different angles. ${ }^{30}$ In turn the internal lack of coherence within the Commission prevented it from playing active policy leadership role, and the 'moratorium' on GMO lingered. In this context the initiation of the WTO dispute can be evaluated as a disciplinary impetus that forced the Commission to finally take necessary steps to break the deadlock.

The challenge in the WTO, being an impetus to make European policies towards GMO at least look trade compatible, has certainly influenced a rapid completion of the regulatory reform. More efficient and workable rules were needed not only to improve trade relations, but also to avoid harm to the competitiveness of domestic biotechnology sector in the future. This is the main underlying idea behind the new regulation. $A$ so-called 'one door-one key' procedure should provide for a simplified authorisation process for release of GMOs into the environment, and of GM food. Controversy remains whether new measures can cope with their double task: to end the malfunction of GMO authorisation procedures (and, consequently, the moratorium), and at the same time to provide high level of human health and environment protection. At first sight, the new Community GMO regulation seems to be indeed the 'safest' and the most stringent in the world, able to comfort that mythically cautious European public. ${ }^{31}$ It is however doubtful that approval of new GM products and reversion of moratorium will lead to a proper functioning of the system of GMO releases. So far it seems that the new European regulatory system, especially requirements regarding setting up a traceability system for each operator (and also in part labelling requirements), is becoming so complex and costly that it could prevent companies even from putting forward submissions for authorisation. Moreover, companies may loose their interest in marketing the approved product by the time when after several years 
long procedures they finally obtain authorisations. ${ }^{32}$ Finally, the impact of the national implementing measures, which are (somewhat delayed) adopted by the Member States in exercise of the competence that is left to them under the new GMO regulation, should be also taken into account. Some Member States eagerly put all possible obstacles in the last areas that do not fall under the scope of Community law, such as for example liability for GMO releases. ${ }^{33}$

In this regard it remains unclear whether the new EU legislation has made a move towards facilitating the GMOs' approval procedures, as requested by its industries as well as unsatisfied trade partners. So far it does not seem that initiators of the dispute would buy the new regime and view the new policies as satisfying their claims. It appears that EU policy-making in the field of GMOs reminds dancing on thin ice - from one side it wants to meet international trade rules from the other - it cannot afford to ignore public hostility towards GMOs. So far it is not very successful in any of them. To make things even more complicated the European biotechnology sector is also quite cautious about the change in the policy. ${ }^{34}$

\section{PART THREE. EU GMO REGIME V. WTO RULES}

In its initial request for consultations within the WTO the US claimed de facto moratorium of GMO approval to be inconsistent with the SPS Agreement (Articles 2, 5, 7 and 8, and Annexes B and C), the GATT 1994 (Articles I, III, X and XI), the Agriculture Agreement (Article 4) and the TBT Agreement (Articles 2 and 5) ${ }^{35}$ Here it should be recapped again that not the compatibility of legislation was called into question, but the inaction of the Commission and the Member States on the issues related to GMOs. 
As in almost every legal dispute (sic! the WTO claims to be a 'rules based system') both sides have their arguments and the analysis of the EU actions related to GMOs can be driven to both directions justifying the EU regime in the light of the international trade law or condemning it. As a result, supporters of either of the two approaches on the both coasts of the ocean find a lot of arguments to plead for the solution that they prefer. ${ }^{36} \mathrm{~A}$ deep conflict between the two systems is already enshrined in their aims. The main aim of the WTO and thus of accompanying treaties is the substantial reduction of barriers to trade and the expansion of trade. ${ }^{37}$ There is, of course, in the preamble to the WTO Agreement also a 'specific acknowledgement about the importance of coordinating policies on trade and the environment'.38 However, the need to respect the requirements of the WTO law prevails. ${ }^{39}$ Agreements are dominated by the 'trade-is-always-good' spirit and allows only for limited and balanced exceptions. ${ }^{40}$ Even the specific WTO agreements, designed to regulate technical standards or measures necessary to protect health, aim at avoiding unnecessary obstacles to international trade or at least minimizing negative effects of these measures on trade. ${ }^{41}$ On the other hand, protection of health, consumer and environment is included amongst the main aims of the $\mathrm{EU}$ and the Commission is obliged in its proposals to take as a base a high level of their protection. ${ }^{42}$

All resulting discrepancies of the WTO and the EU legal systems stem from this main ideological difference and as long as the Panel has not taken its decision, argumentation according to both lines ('free trade' or 'safety') is merely a more or less well-reasoned speculation. In order not to reiterate the litanies of arguments of the prominent researchers, only the most controversial and ambiguous legal points of the dispute will be shortly discussed in the following parts. After examining the moratorium in the light of the WTO rules, the question of qualification of the actions, which EU makes after the beginning of the dispute, will be looked at. 


\subsection{Moratorium and GATT: national treatment, likeness and exceptions}

This trade dispute concerns market access barriers that are not caused by measures taken at borders, but by differences in domestic regulatory systems of biotechnology products. The US claim that European measures against GMOs constitute a protectionism against agricultural products produced in the US. Protective treatment of domestic goods in turn violates international trade law, specifically Article III of the GATT (the "National Treatment Clause").43 The Panel thus should assess if the EU regime for agricultural biotechnology products are appropriate from the perspective of trade, thus reaching deeply into the domestic regulatory competence on the issue. Article XX GATT, however, provides for an exception from Article III GATT and allows members to make regulations that otherwise violate the GATT when such restrictions are 'necessary to protect human, animal or plant life or health'.

As Article III requires non-discrimination between like products ${ }^{44}$, the first major problem that arises when assessing European GMO regime is whether GM products and conventional products are like products. To give an example, first it should be answered if, e.g. chocolate, consisting lecithin of GM soybeans, is substantially the same product as the chocolate with lecithin of 'normal' soybeans, while is impossible to detect the physical difference between the two in so highly processed food products. The main question arising here is whether a state can differentiate food products containing non-traceable GMO only on the basis of the production method (i.e. genetical modification) of their ingredients. The main difficulty related to the notion of likeness of products is that so far there is no possibility for differentiation between products with regard to the method of production. ${ }^{45} \mathrm{~A}$ so-called PPM problem (whether production and processing method may rend a product 'unlike') in the framework of the GATT was touched for the first time in Tuna-Dolphin dispute ${ }^{46}$, where the panel denied that the PPM 
could influence likeness of product 'as a product'. While this ruling caused major public dissatisfaction and was not approved by the DSB, in the following similar Shrimp-Turtle case ${ }^{47}$ the Panel avoided pronouncing on the issue of likeness of products with different PPMs. Therefore, it remains unsettled for the time being, whether products could be considered 'unlike' and consequently be treated differentially, when they are obtained as a result of different processing procedure. It is rather doubtful, whether the EU could justify under the WTO law its $\mathrm{GMO}$ regulatory regime on the basis that GM products differ from their traditional counterparts merely because of the method in which they are obtained.

Even if GMO's panel would manage again to avoid answering the question on 'likeness according to the PPM', it will have to determine likeness of GM and non-GM products, according to traditional 'four

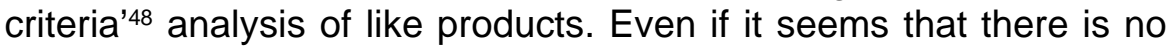
way to achieve perfect likeness among biological products, the pertinent question is whether there are differences that are critical and important enough to distinguish the products under the GATT. In this regard arguments in favour of likeness of GM and non-GM products would be their physical characteristics and market competitiveness, while consumers' taste and habits as well as 'risk element' could provide the EU with an argument for 'unlikeness' 49

Interestingly enough in the European regime itself, there is no coherence on whether all GM products and non-GM products are 'like' or 'unlike'. Namely the concept of substantial equivalence lacks uniform definition within the EC..$^{50}$ In the cited Monsanto judgement the ECJ ruled that substantial equivalence does not preclude „novel foods [i.e. foods obtained from or containing GM products] which display differences in composition that have no effect on public health from being considered substantial equivalent to existing foods"(emphasis added). ${ }^{51}$ The ECJ 
thus makes the unlikeness (as opposed to substantial equivalence) conditional not on the mere existence of GMO in a food, but on its actual effect on public health. That allows anticipating that the EC would rather base its arguments on the risk for human health then merely on the likeness issue. And the protection of human, animal, plant life or health is one of the grounds for a general exception from GATT obligations under Article XX (b). However, the uses of Article XX defences are restricted not only by the conditions of the Chapeau of that article ${ }^{52}$, but also by the procedural conditions, set forth in two lex specialis agreements, namely the SPS and TBT Agreements. ${ }^{53}$

\subsection{Authorisation of GMO and the SPS Agreement}

The SPS Agreement supplements the above-mentioned exception of Article XX (b) GATT. Rather than seeking to encourage reduction of trade barriers the SPS Agreement establishes procedure for examination of trade barriers that inevitably arise as a consequence of national measures aimed at protection of health or safety. The SPS rules apply only to so-called sanitary and phytosanitary measures as defined in the agreement. ${ }^{54}$ In the current case the SPS Agreement is relevant only to the regulatory regime of the commercial release of GMOs and not to labelling issues or traceability regime.

The Agreement entitles WTO members to adopt and maintain SPS measures (e.g. a ban of a certain product) that are necessary to protect human and animal health and life. ${ }^{55}$ SPS measures are considered to be one of the very few types of measures that could benefit the consumer. ${ }^{56}$ However, a right to adopt SPS measures is subject to certain conditions. The SPS measure has to be: 1 ) applied only to the extent necessary; and 2) based on scientific principles, i.e. not maintained without sufficient scientific evidence. One further condition reiterates the chapeau of Article XX GATT (i.e. prohibition of arbitrary discrimination or disguised restriction of trade). 


\subsubsection{Measures allowed under the SPS Agreement}

The provisions of the SPS Agreement in the context of the GMO case mean that the EU could have banned the GMO from its markets if it could have provided acceptable evidence of safety and health risks. In such case complainants would have been left without remedy under the SPS Agreement. ${ }^{57}$ As the certainty of safety and health risks caused by the GMO falls into rather ambiguous area, it is not easy to distinguish protectionist SPS measures from justified ones. Most often-legitimate health concerns go parallel with recurrent incentives to protect national producers in the coulisse of the adoption of the SPS measures.

The SPS Agreement sets a presumption that a SPS measure is trade compatible when it conforms to international standards, guidelines or recommendations, developed by the relevant international organisations ${ }^{58}$ The SPS measure, setting a higher level of protection then it would be achieved by measures based on international standards, is subject to the conditions of Articles 3(3) SPS (scientific justification) and Article 5 SPS (risk assessment procedure) ${ }^{59}$ Stricter protection, then that provided by international standards, would be compatible with trade rules only when it is scientifically justified and based on risk assessment. The only narrow exception to the obligation to base such stricter SPS measures on risk assessment is provided by the Article 5 (7) SPS, which reflects to some extent a precautionary principle. ${ }^{60}$ To sum up there are three main criteria that a national measure must meet to be SPS-compatible: (1) conformity with international standards, (2) result of scientific risk assessment or (3) precautionary measure, where scientific evidence is insufficient. 


\subsubsection{GMO regulation as a SPS measure: international standards, risk assessment, precaution}

In the light of the legal framework mentioned above the GMOs' authorisation poses several problems at all three levels: international standards, risk assessment and precaution.

\section{International standards}

Firstly, as far as the international standards and guidelines are concerned, the SPS Agreement refers to three international bodies. The most important in the GMO context is the work in Codex Alimentarius Commission on standardisation of rules on human safety and health. Although the work on GMO related issues is taking place in several Codex Alimentarius working groups, the consensus on needed international standards is not easily reached. ${ }^{61}$ It is crucial to note that discussion parties in Codex groups are in fact the same ones as those in dispute over GMO products in general, which substantially limits the potential of compromise. Moreover, the work on GMOs differs a lot from the product-by-product standardisation. Being a complex crosscutting issue, the GMO health and safety standardisation seeks to encompass more than safety of a certain product - more general rules for risk assessment, labelling, and traceability. Where the risk assessment of GMO products is concerned, Codex guidelines intend to identify new or altered hazards relative to the conventional counterpart, rather than trying to identify every hazard associated with a particular food product. ${ }^{62}$

Consequently international standards are silent about danger of a particular GM product or, on the contrary, whether a particular GM crop should not be banned from national market as being safe. They only provide for a procedure for the assessment of safety. However, EU's moratorium on GMOs should not be evaluated in the light of this risk assessment procedure, as Codex guidelines were first adopted only when the EU moratorium has been already in place for a while. 


\section{Risk assessment}

The second major problem that arises when evaluating the GMOs regime under the SPS Agreement relates to the requirements and boundaries of the risk assessment. While Article 5(2) SPS provides for a list of criteria that should be taken into account in the risk assessment ${ }^{63}$, it was expected that WTO dispute settlement activities should confirm whether this list is exhaustive or if other, especially non-scientific factors (precaution or consumer concerns), may be also considered in risk assessment. ${ }^{64}$ In Beef Hormones case the Appellate body admitted that the list of factors is non-exhaustive, almost dramatically adding that also should be considered:

'risk in human societies as they actually exist, in other words, the actual potential for adverse effects on human health in the real world where people live and work and die'(emphasis added). ${ }^{65}$

Thus interpretation of factors for risk assessment by the $A B$ in Beef Hormones leaves the possibility to include non-economic factors, though commentators harshly attack such possibility, as it would open the way for too protectionist policies. ${ }^{66}$ Despite this broad definition of the risk assessment, the EC import prohibition in Beef Hormones was found not based on a risk assessment. ${ }^{67}$ It is claimed that also in the GMO dispute the EC made the same mistake, when it just lamed GMO authorisations without conducting any studies to determine the potential risks to human health from the release of GMOs. ${ }^{68}$

\section{Precautionary measures}

The third and crucial problem with the GMOs in regard to the SPS Agreement is that reliable scientific information on their safety and effects on health or environment in a long term is simply missing (or in a more formal language - is insufficient). Significant scientific 
uncertainty, which genetic modification inevitably involves, is highly important to both - regulators and consumers - at least in Europe. In relation to the scientific information the Panel acknowledged already in Asbestos case that settling a scientific debate is not in its function, as it is not composed of experts in the field. The Panel would limit itself to a mere determination whether sufficient scientific evidence exists to conclude that there is a risk for human life or health and that the measures taken by the Member are necessary in relation to the objectives pursued. ${ }^{69}$ However, in the GMO case the Panel will have to decide on the 'insufficiency of evidence', which in itself can be another 'scientific debate'.

While 'scientific uncertainty' is not the same as 'insufficient scientific evidence', the WTO case-law is not clear what influence the first has to estimating the second. ${ }^{70}$ Although this paper is definitely not aimed at determining the credibility and safety of the products of modern biotechnology, still 'uncertainty', 'ignorance' and 'ambiguity' are the words often coming together in the context of the effects of different uses of GMOs. As far as the provisions of the SPS Agreement are concerned, the case 'where relevant scientific evidence is insufficient' is covered by Article 5(7) SPS. This article is understood to govern 'precautionary measures' in the light of WTO. ${ }^{71}$

A precautionary measure under Article 5(7) SPS also has to fulfil several conditions, the most important of which is the provisional character of the measure. Moreover, a state is obliged to seek to obtain any additional information and review the precautionary measure. Obviously, none of these conditions (i.e. provisional character and renewable measure) was fulfilled when authorisations of particular GMO products were stalled in the EU. On the other hand, it could be claimed that the moratorium itself was a certain precautionary measure: as it is lifted up now, it was only a 'provisional' measure, which continued untill 
appropriate procedures and safety assessments were put in place. Thus a broader dispute on risk and precaution in case of insufficient scientific evidence on (un)safety of GMO should be looked at.

\subsubsection{Precautionary principle}

The role and employment of the precautionary principle is perhaps the most contentious area in the GMO dispute. Commentators cannot agree on its definition and applications and this principle is not interpreted in the same way on the both sides of the ocean. To put it simply, the precautionary principle consists of two elements, first: „philosophical authority ... to take public policy or regulatory decisions about the protection of the environment or human health in the face of scientific uncertainty, or worse, ignorance“ 72 , and second: „basis for acting in advance of scientific proof of harm to address uncertain but significant risks". ${ }^{73}$

'Europeans' are considered to be generally more cautious in their policies than their counterparts on the other side of the ocean, while it is not necessarily true empirically. ${ }^{74}$ In the case of GMOs American policy is in fact much more permissive..$^{75}$ The precautionary principle causes so much controversy, because it is difficult to apply it within regulatory framework based on rationality. It also reveals a multifaceted problem of integration of science in a complex decision-making under conditions of uncertainty. ${ }^{76}$ From the legal point of view the reversed burden of proof in the European approach of precaution is the most important issue, which causes most of the existing troubles. While in the face of scientific uncertainty one cannot really have a proof that something is harmless, there is a legitimate question, how much and how deep should one investigate looking for a potential harm and what kind of proof matters. 


\section{Precaution $v$. risk assessment}

Because of many uncertainties precaution is an inherent element of the risk analysis of GMOs related hazards. Many put precaution in contraposition to science ${ }^{77}$, however under conditions of uncertainty and ambiguity, both conventional (i.e. cost-benefit based) risk assessment and precautionary approaches necessarily include considerations that are not purely scientific. ${ }^{78}$ Assertion that risk assessment is based on 'pure science' would only undermine the credibility of regulatory institutions and the associated science, thus raising the chances for flawed decisions. ${ }^{79}$

As mentioned previously, under conditions of scientific uncertainty, where no proof exists that something is 'really' safe, it is not clear, where the risk assessment should stop. The precautionary principle states, that one should always err on the safe side. In the EU law (in the Commission's decisions as well as the Court's jurisprudence) the question of balancing of different economic-social-environmental interests without granting unjustified supremacy for one over the other is raised. Here the cost-benefit, which means that one should investigate as much as is possible into the particular economic circumstances, comes into play. Again the limit, where the investigation should stop and assume safety or risk is not defined.

The main problem of employing the precautionary principle to justify EU measures on GMOs in the light of Article 5(7) SPS and the SPS Agreement in general is linked to different perceptions of this notion across the ocean, and the uncertain role it has the WTO.

Different perceptions of the precaution and their impact on the dispute

In the EU law the precautionary principle is 'one of the most powerful weapons on the environmental arsenal' 80 , and lately it is strongly 
supported by the Commission at least in its policy documents. In its Communication on Precautionary principle the Commission acknowledged the broad range of definitions of the precautionary principle and awarded it an important role in the EC decision-making process. ${ }^{81}$ It is important to stress that according to the Commission not only an unacceptable risk and scientific uncertainty have to be taken into consideration, but also public concerns (socio-economic information, technological perspectives) must be considered as additional factors. ${ }^{82}$ Finally, according to the EU perception of precautionary measures such measures may be permanent (as opposed to the measures provided for by Article 5(7) SPS). However, a stick has two ends however and in the area of risk regulation the Member States start claiming the same precautionary autonomy, which the Commission claims to the international community, in their intraCommunity relations..$^{83}$

Recognition of the principle by the Community judicature is, however, less unequivocal, and therefore is exercised more cautiously. ${ }^{84}$ The CFI used to include in its judgments on the precautionary principle the statement that public values, such as human health, should take precedence over economic considerations. ${ }^{85} \mathrm{~A}$ very wide margin of discretion that CFI left for Community institutions was considered to put European precautionary measures in an unfavourable position in case of 'WTO proof'. ${ }^{86}$ And so it happened.

Later the ECJ, however, was more moderate about the extent of the discretion granted to the Member States. ${ }^{87}$ As the ECJ is not much concerned with compatibility of precautionary measures on GMO with the international trade, its considerations about the risk and precaution compete only with those about the internal market. Thus the ECJ is in fact forced to give equal weight to both these interests: the precautionary protection (of human health) and free movement of 
authorised GM products within the Community. The ECJ is hence also placed in front of the conflict between two major principles of Community law - the free movement and the precautionary principle. As a consequence, European approach to precautionary principle becomes two-sided. On the one side invoking precaution is hardly permitted to a Member State against the other one by the Community courts. On the other side the Commission favours the use of the precautionary principle against third countries. In practice this means that the precautionary principle is not an easily applicable instrument, in part probably due to the fact that trade interests of the EU (firstly - intraCommunity, then also - with third countries) are often given priority over environmental ones.

At first glance interpretation of the precautionary principle in the WTO regime (and the US) is similar, if not identical, as the precautionary principle is designed to help in situations where the regulators are faced with uncertainty. Yet the similarities are rather superficial, as the principle is rationalised in fundamentally different ways. ${ }^{88}$ The most important differences concern general regulatory issues, such as social and scientific rationality in GMO regulation, approaches to risk assessment and risk tolerance, perception of precaution, as well as role of science on the both sides the ocean. Current divergent trends in biotechnology can be attributed also to the different belief about the role of science in the society.

The current conflict between the EU and the WTO regimes stems thus from the fundamental difference between their priorities: respectively safety issues or the free trade (where safety measures can only be based on 'pure science') ${ }^{89}$ Moreover, in Beef Hormones the Panel stated that the precautionary principle has been incorporated and given a specific meaning in Article 5(7) SPS..$^{90}$ The AB added that this principle does not serve as a ground for justifying SPS measures 
that are otherwise inconsistent with the obligations set out in particular provisions of the SPS Agreement. ${ }^{91}$ It is to be seen in the next months, whether the Panel would follow the same line of reasoning on precaution in case of the GMO. It is worth noting that in neither of the two other WTO cases on food safety Australian Salmon, dealing with a ban on salmon import on grounds of possible diseases, and USJapan agricultural products, contesting Japan's quarantine and fumigation restrictions on certain products, the DSB was satisfied with the submitted scientific evidence. The position of the EU is even more complicated because of the safeguard measures adopted by the separate Member States: those safeguard measures are at odds with Community legislation and their compatibility with a balanced approach to the precautionary principle is rather questionable.

\section{Precaution as a reflection of the MEA problem in the WTO}

The final, but still major problem related the precaution in case of GMOs and trade rules, reflects a more general problem related to taking into consideration of environmental issues in the WTO. If the GMOs dispute is really to be called 'a supra-national battle' over science and precaution ${ }^{92}$, then this battle does not take place only in one level namely the WTO. Former trade partners (if EU and US relations in light of GMOs can be called partnership at all) put the GMO dispute on other international arenas as well.

Under the auspices of UNEP Convention on Bio Diversity (1992) the famous Cartagena Protocol, to which the EU is a party while the US are not, was adopted in 2001. ${ }^{93}$ This treaty is deemed to be a precautionary instrument for international risk management that aims at establishing principles and rules for decision-making on trade in GMOs. ${ }^{94}$ The Biosafety Protocol requires the parties to apply the 
precautionary principle in the case of scientific uncertainty (Articles 1 , $10(6)$ and $11(8)$ ) and strengthens the prerogative of importing nations. Contrary to the SPS Agreement, the Biosafety Protocol contains neither a requirement for provisional character of a precautionary measure nor any requirements for periodic review of it.

If according to the Biosafety Protocol, the importing state has a right to deny access to a GMO on the basis of the precautionary principle, the question arises which rules prevail: those of the Protocol or of the SPS Agreement. Although in this regard, the Cartagena Protocol is considered being 'a treaty that may be too self-conscious of its relationship with international trade law'95, there is no final solution. ${ }^{96}$ The preamble to the Protocol seeks to reconcile two quite contradictory solutions: it recognises the existing rights of WTO members while at the same time not subordinating the Protocol to other international agreements. Hence the Protocol viewed separately does not help much to find a solution to the unpleasant WTO/MEA problem.

The WTO v. MEA (Multilateral Environmental Agreements) conflict first started with Tuna Dolphin case and by some commentators was considered effectively solved in the Shrimp Turtle case. ${ }^{97}$ However, the fact that the US do not revoke their claims after the EU could be considered to have lifted the moratorium, may be explained by the wish to obtain the clarification of WTO/MEA relation. ${ }^{98}$ As it is not likely that in the foreseeable future any creative political resolution addressing this problem will be adopted within the WTO Committee on Trade and Environment, thus the ultimate resolution seems to be left for WTO dispute settlement bodies. It is, however, disputable whether the rulings of panels and the $A B$ are able to resolve much deeper political tensions. In the absence of political conciliation on the issue ${ }^{99}$, the future does not look bright for 'peaceful' resolution of this particular GM dispute 
under auspices of Cartagena Protocol. Neither the general greening of the WTO could be expected. ${ }^{100}$

\subsection{The change in the EU regime and the TBT Agreement} It would have been too simple, if the European GMO regulation had caused problems related only to the SPS agreement. It also raises serious doubts in the light of the provisions of the TBT Agreement.

The TBT Agreement, which aims to prevent producer protectionism by non-tariff restrictions, requires non-discrimination between like products in application of mandatory regulation or labelling related to health and safety issues. GMOs related question in the framework of application of the TBT agreement is whether conventional non-GM products and GM products could be treated differently, where GM products are substantially equivalent to non-GM products. The TBT Agreement covers only those technical standards and regulations, which are not covered by the SPS Agreement. ${ }^{101}$ The labelling of foods derived from the biotechnology is designed to meet 'consumer's right to know' requirement, but no longer 'health and safety' reason, because authorised GM products are assumed to be safe as evaluation of their safety goes before placing them on the market (and before labelling them). Thus the EU's labelling and traceability regime falls under the TBT provisions, while the moratorium on the approval of GMOs, as it stood till May 2004, does not seem to. ${ }^{102}$

The new EU's regime and mainly the oncoming application of labelling and traceability requirements pose justified questions on its conformity with the TBT agreement. Difficult to implement mandatory EC rules on labelling (not to mention those on traceability) will not easily pass scrutiny under the TBT Agreement because of the points indicated bellow. Firstly, it is not clear if the system of mandatory labelling is compatible with the WTO rules. Voluntary, participatory, market-based and transparent environmental labelling schemes are generally agreed 
to be potentially efficient economic instruments by most WTO Members. In addition, they are, generally, viewed to be less trade restrictive than other instruments. ${ }^{103}$ Thus not discriminatory voluntary environmental labelling schemes would likely to be approved even if they are used to describe production method (as distinct from the product itself). On the contrary, obligatory GM labelling gives rise to controversies, comparable to those raised by the access to market issue. Secondly, this labelling and traceability regime, although argued to be justified by strong demand from European consumers to label GM foods, is based on the method of production and not on the product itself. ${ }^{104}$ Yet, a technical regulation, covered by the TBT Agreement, 'may also include or deal exclusively with terminology, symbols, packaging, marking or labelling requirements as they apply to a product, process or production method (emphasis added). Inclusion of the PPM in the definition of technical regulation allows argument, that contrary to the 'likeness' under the GATT, the TBT Agreement permits to differentiate technical regulation (e.g. labelling regulation) of products according to the PPM. Although, according to traditional 'hard science' based analysis there would be no product related differences (that could serve as criterions for specific labelling and traceability requirements for GMOs), the EU could justify its labelling and traceability regime as applied to the PPM. Thirdly, like most of the WTO agreements, the TBT Agreement requires that respective measures would not create unnecessary obstacles to international trade, i.e. that they would be proportionate to the legitimate objective they pursue. Whether labelling and traceability of the GM products, according to the EC rules, are technically and economically feasible, is a matter of substantiation. It depends largely on how the rules will be implemented in practise.

On the other hand, under the TBT Agreement there are aspects that make it easier to find justification for EC rules then under the SPS 
Agreement. The TBT Agreement refers also to the standards of $\mathrm{Co}^{-}$ dex Alimentarius Committee. As in case of the SPS Agreement, conformity with international standards creates a presumption of conformity with the TBT Agreement. However, as in case of the risk assessment under the SPS Agreement, those international standards, i.e. Codex guidelines, do not answer all relevant questions. Consensus on the labelling of food products obtained through GM techniques has not been reached although discussions on the subject last nearly ten years. According to the latest draft, obligatory GMO labelling would be required only when the composition of food were 'no longer equivalent to' or, alternatively, 'differed significantly' from the initial product. ${ }^{105}$ This proposal differs substantially from the view advocated by the EU whose position is that mere process of genetic modification consitutes a sufficient ground for obligatory labelling. The issue of traceability has experienced even a more bumpy way in the Codex Committee. Some form of it, called 'product tracing', could now be found among agreed risk management measures as one of the socalled 'post-market monitoring' measures. ${ }^{106}$ The 'post-market monitoring' would require a case-by-case consideration of a need and utility of each measure while EU regime foresees automatic tracing for all and every ${ }^{107}$ product containing GMOs after placing them to the market. This difference leaves room for various interpretations when taking a decision whether traceability of a particular GM product would be justified.

Finally, if the modified EU regime (in particular labelling and traceability schemes) falls outside the SPS Agreement and thus should be analysed under the TBT Agreement, the latter is more lenient in terms of possibility to find a justification of national measures for reasons of public safety, environment and other objectives. ${ }^{108}$ This clearly nonexhaustive list of exceptions would allow the EU to include also other socio-economic considerations, such as consumer protection and preferences to justify labelling and traceability schemes. 
Summarising the analysis of the GMO dispute under the WTO regulations, it appears that there are numerous points of conflict and discrepancies. Not smaller in number are different ways of interpretation of main relevant WTO agreements: the GATT, the SPS and the TBT. Which WTO agreement will apply to a particular measure challenged in the GMO dispute will therefore largely depend on the policy objectives behind that measure..$^{109}$

Qualification of the lifting the EU's de facto moratorium and recent approvals according to the new legislation constitute a separate point of interest. Despite the fact that the EU quite visibly tries to abandon its 'moratoria' measures, the US show no sign of backing down yet. Although the US has a possibility to withdraw the complaint it does not seem very keen to use it. The reason behind the behaviour of the US could be the need for a definite clarification of a broad range of GMO related issues in the light of the trade law that makes the US and its co-complainants to uphold the present dispute. If the US succeed proving the inconsistency of the EU moratoria measures, it will be rather a 'moral satisfaction', as the EU would already have implemented the claimed remedy - putting an end to the de facto moratorium. However, lifting of the moratorium is not resulting in freer trade in GM products yet, as the new labelling and traceability system remains stringent enough to constitute a significant trade barrier. It is more likely that a second round of GMO war, related to consistency of the new traceability and labelling requirements of the EU with its undertakings under the WTO regime, will be launched.

\section{PART FOUR. DISPUTE SETTLEMENT PROCEDURE IS LAUNCHED... AND SO WHAT?}

In three previous parts the key issues of the dispute were presented together with problems that arise from the conflict of the EU and the WTO regulatory systems. To sum up, the WTO dispute settlement 
bodies are facing a set of long-standing complex questions and answering them is crucially important for the further development of the 'rules based' system of the world trade law. Each of these issues raises a number of controversies: the problem of likeness (of GM products to non-GM products); the depth of risk assessment (and the role of science and non-scientific factors); definition and scope of application of precautionary measures under the SPS Agreement; evaluation of national regulatory mechanisms, where the required international standards are missing; relation of trade rules with the multilateral environmental agreements (the SPS Agreement versus Cartagena Protocol); and the relation among the different WTO instruments. This array of legal problems shows that the interaction of these two systems (the EU and the WTO) is rather complex, but it does not answer the basic question, whether the biotech related issues, one of the freshest 'pommes de discorde' in the field of international trade should at all be solved in the framework of the WTO.

\subsection{Is the WTO is a proper forum for biotech related issues?}

Biotech issues are lately a sensitive issue and is discussed in many international foras (in the context of the topic of this paper the work in the Codex Commission, as well as in the Conference of Bio-Diversity Convention and WTO Committee on Trade and Environment are of particular relevance). Links between trade related issues on the one hand and food safety and environmental requirements on the other press international community to develop coherent rules for GMO related issues. The first and basic precondition for successful work in any of the international foras is a political will to find a consensus. The $\mathrm{EU}$ is making significant efforts in all those foras to adopt provisions that would play to its hands - such as the broader precautionary principle, rules on traceability - while the US is constantly opposing to such attempts. 
In this light it is highly questionable whether the WTO may act as an ultimate interpreter of the GMO related issues for several aspects and reasons. Firstly, it can be claimed that the WTO cannot properly take into account potential socio-economic impacts of the GMOs in all the countries, since these have different conditions and priorities. ${ }^{110}$ Secondly, the question of relation between the trade rules and the MEAs, which was already briefly mentioned, raises doubts if the WTO should be the place where the question of their subordination is resolved. Finally, procedural deficiencies (limited investigation possibilities, growing number of cases of non-compliance after final DSB disputes ${ }^{111}$ ) of dispute settlement mechanism within the WTO do not reinforce the WTO's image of an instance where the GMO dispute could be effectively solved. Having in mind the abovementioned situation, the possibility to include non-economic considerations to the WTO framework through the GMO dispute will be looked at further in the text as well as the possible outcomes of the conflict.

\subsubsection{Opening the WTO to non-economic issues}

The 'big' controversy of this GMO dispute is that it is not a mere trade conflict challenging the EU regulatory regime, but it also triggers deeper non-economic issues. It touches upon the environmental considerations and their importance to the 'free trade aim', as well as it raises question of possible introduction of consumer preferences. It also poses the more philosophical problem, what risks (how certain or uncertain) a particular society is supposed to take and what role science should play in this society, in other words, where to draw a line between cautiousness and 'trade-is-always-good' approach.

Although continuously debated, opening of the GATT to the noneconomic issues (ranging from environmental issues to human rights standards) so far was not achieved. The question remains unanswered 
though if the WTO has a mandate to settle such disputes related to such non-economic issues on the base of merely the trade rules. On the other hand, opening of specific SPS and TBT agreements to noneconomic issues that are difficult to measure (consumers fears and preferences, for example) raises fears of putting into danger the balanced WTO mechanism. It is argued that the admittance of the non-economic issues to the WTO framework would make it very difficult if not impossible to detect when countries in fact indulge in simple producer protectionism ${ }^{112}$, which from the point of view of WTO, seems to be presumed underlying reason for all national regulation. Although a more restrictive political and regulatory framework was an impediment to the progress of European biotech industries, rather than their protection ${ }^{113}$, this argument could not be employed to defend EU's position.

As the WTO agreements presume producer protectionism and do not take into account consumer preferences, the WTO members are trapped between their international WTO obligations and domestic consumer demands. ${ }^{114}$ Such entrapment is blatant in the case of the EU GMO regime. The Commission at the same time is viewed as a 'bad guy' who wants to foist GM food to the bristled up European consumers from one side, and as untrustworthy trade partner that circumvents trade regulations in various ways, thus frustrating its trade partners from the other.

While consumer protection is not the sole 'excuse' for the EU GMO regulation, links could be also drawn with the environmental protection as a justification ground. Previously discussed Cartagena protocol suggests, for example, a risk mitigation strategy that would go beyond the 'hard' science-based decision-making, and take ethical, political, and socio-economic considerations into account (Article 26). Such individual GMOs strategies would also vary from country to country, as they do now. Should such differences in perceived 'danger' of GMOs 
by the societies be levelled or is it still permitted and why should it be the WTO that decides on the answer to this question? It is understandable, why the US and their co-complainants wanted to bring the issue before the WTO, although 'trade' is not the main issue of this dispute. Most of other international stages, in which questions related to the GMOs and modern biotechnologies are addressed, do not and cannot provide a way for effective dispute resolution. Enforcement procedures of the relevant MEAs (monitoring and reporting, e.g.) lack efficiency when compared to the dispute settlement process in the WTO. Thus the WTO process is much more powerful mechanism for the resolution of trade and environmental conflicts. That in turn leads WTO members (at least some of them) to bringing GMO related questions to the framework of the WTO.

\subsubsection{Possibility of a negotiated settlement}

The final doubt on whether the WTO is an appropriate place to solve this biotech dispute lies in the very nature of the dispute settlement mechanism. Although highly institutionalised framework with a balanced set of rules is the main element of the dispute settlement mechanism it never excludes a possibility of a negotiated settlement in any stage of the dispute. ${ }^{115}$

On the one hand, such possibility to negotiate the outcome would probably leave all those important questions and problems, which were discussed above and which need the answer, unanswered. In this sense the GMO dispute would be solved under-the-table way depriving international community and separate states without guidelines on how to balance their biotechnology regulation with the requirements of free trade. Furthermore, despite the fact that compromise would mean that the US and the EC have found a common point of view, such outcome is unlikely to satisfy their voters. Negotiating out of the dispute would make the WTO dispute settlement look less transparent, and this would 
give an additional argument to the opponents of the GMOs in Europe to claim that the undemocratic Commission with the non-transparent WTO have silently agreed something behind the closed doors.

On the other hand, although in some degree an amicable resolution of a dispute would lessen political tension among the involved parties considerably ${ }^{116}$, it is not likely to happen having the ideological nature of this dispute. The basic principle in question goes beyond simple mere requirements of authorisation to place the GMOs on the market, but as repeatedly mentioned, concerns substantial issues of diverging regulatory regionalism across the ocean, inclusion of non-economic problematic to the WTO etc... The US and the EC having completely opposite views on each of the questions do not seem to be keen to soften their positions. One more reason, why the opponents will decline the option of negotiations on the issue is the fact that the decision of the Panel (and the AB decision, when it comes) will not necessarily be complied with. The likely development of the EC not properly implementing the negative decision is discussed bellow.

\subsection{Will the EU enforce a negative decision?}

According to the analysis presented in the preceding chapters, the main initial plea of the US in the dispute is likely to be satisfied and the de facto moratorium to be found inconsistent with the WTO obligations. It is likely that the Panel will support arguments of the US and its cocomplainants and recognise that the EC once again has 'acted inconsistently with the requirements contained' in certain WTO provisions. Such resolution, however, will be only 'harvest of trouble' as elegantly named by Isaak/Keer, already referred to above.

Firstly, the ruling against the EC will fuel hostility towards the WTO. In fact nobody, except the directly concerned, will read three hundred pages of the Panel decision, which presumably will contain a logical 
and intelligent reasoning, and give answers to many of the problems posed by the dispute. The headings of press releases (like 'the WTO rules against EC GMO regulation' in the mildest form) will be the material on which irritated Europeans will base their opinions. This decision will be shown not as a decision against the inaction of the EU and its incapability to perform in the field of biotechnologies during the 90 s, but rather as one more WTO's decision against human, animal health and environment. It will be seen as denying regional $\mathrm{EC}$ regulations on the GMO, which are deemed to be aligned with public opinion and consumer preferences in this area. Secondly, the negative ruling will be portrayed as one more victory of big-and-bad multinational firms that develop and consequently want to export the GM products, rather then of biotechnology itself.

Moreover, it will certainly upset the $\mathrm{EC}$ and there would be danger that it could be discouraged from pursuing reforms of the CAP in order to move forward with the negotiations of Doha Agenda ${ }^{117}$. The negative decision could even de-motivate the EC from further completing and consistently implementing the new regulatory framework on biotechnology (which at the moment seems to be the only possible concession that the EC is ready to offer for its trade partners simultaneously making compromises with its constituency). Finally, the environmentalists will again raise their claims that trade liberalisation, promoted by the WTO, is achieved only at the expense of environment, if the Panel decides against the Cartagena protocol as well. ${ }^{118}$

Bearing in mind that points of conflict in this dispute between the WTO regime and the EU policy are numerous, the 'negative' effect of the ruling might be softened in admitting that the EU was still right in some aspects. For example, if the Panel recognised that only the moratorium was trade-inconsistent, but that with the new regime the EU has indeed 
changed its performance in respect of the $\mathrm{GMO}$, then the request to bring measures of the EC into conformity with its WTO obligations would become obsolete.

It is clear that the enforcement is a critical phase of the dispute. As quite recent experience in the in some sense similar Beef Hormones dispute shows, the EC is not going to smoothly comply with the negative ruling of the WTO. The final AB decision in Beef Hormones was adopted in January 1998 and unsurprisingly the EC has declared that it would require a 'reasonable period of time' for the implementation of the report because of impracticability of the immediate compliance. ${ }^{119}$ After the EC failed to comply with its obligations within fifteen months 'reasonable period', the US went further in the procedure and in May 1999 it requested authorisation of suspension of the tariff concessions. Thus the formal resolution of the dispute did not lead to actual implementation of it, but all possible procedural actions were taken to delay such implementation. Even despite retaliation measures that were started in 1999, the EC first communicated its complete implementation in October 2003. ${ }^{120}$

Another arguable question is whether the communicated directive indeed implements the WTO decision, as it leaves the uses of the hormones in dispute 'provisionally' suspended ${ }^{121}$. The EC has always affirmed that it wanted to comply with the reports adopted, but never showed willingness to withdraw its measures ${ }^{122}$. The US has in turn seen EC's 'implementation' as an affront and thus looked for the ways to strengthen pressure on the EC, for example by seeking to apply the highly discussed 'carrousel' retaliation. ${ }^{123}$

Since the retaliation does not help to gain access to the wanted markets, the implementation procedure, which is supposed to put an end to the trade restrictions, resulted in even larger trade distortions in Beef Hor- 
mones. Hence the lengthy dispute settlement procedure, the uproar caused by the reports and the strengthened tension between the parties did not serve to achieve the pursued goal - removal of trade barriers. On the contrary, it locked the parties in the vicious circle of quarrelling on the same problem further on instead of co-operating to solve it. As the expansion of a trade conflict is not in the interest of either party, it also proved that the WTO dispute settlement mechanism does not have effective enforcement if there is no political will, which is very harmful to the credibility of this mechanism and the organisation itself. The fact that the EU, being one of the main supporters of the trade liberalisation, does not obey to the rules it agreed upon seriously undermines the WTO order. This loss of the credibility by the WTO will only increase if the EC systematically ignores or circumvent for the second time in turn a negative decision having such a high profile as the GMO decision. The probability that the $\mathrm{EC}$ will follow the similar pattern of behaviour in case the GMO dispute is not solved in its favour is very likely. Given the pressure from the Member States (which is caused in the large part by the public hostility to the GMOs) it is unimaginable that the EU would switch to the 'North-American' style of biotechnology regulation. The only thing that the EC would probably implement is the lifting of the moratorium (which is already happening) and properly implementing its current regulation. Finally, a decision against the EU will have rather negative impact on the biotechnology as such, by maintaining especially weak public acceptance of the GM products in Europe. Moreover, development of the biotechnology is claimed to be hampered by the further regionalisation of the regulation of GM products, as other countries will be forced to chose between the EU-compatible or WTO/North America-compatible GMO regulation, depending on that which markets they consider more important. Such regionalisation of $\mathrm{GMO}$ regulations could in turn boomerang the multilateral trade liberalisation in the form of a protectionist block. ${ }^{124,125}$ 


\subsection{An Alternative: conditional admittance of GMOs}

The previous part described the 'doom' scenario of this WTO dispute that could result in deepened transatlantic tensions, a further loss of credibility of the WTO and a failure to achieve multilateral solution to the problem. Before the report of the Panel is adopted, any prognosis on the outcome is a mere speculation. Indeed one cannot exclude that also the approach adopted by the EU will be favoured, as the European precautionary approach is still based on insufficiency of scientific evidence and to some extent also on international standards (certainly on Cartagena protocol and, depending on interpretation, on Codex principles). Moreover, if the Panel finds that the moratorium is indeed lifted there is no much sense in condemning it. Thus the possible outcome depends on the interpretation of all the individual issues discussed above. Legal background allows broad range of interpretations and therefore almost any outcome is possible. In the following paragraphs, a more workable solution to the problem of the GMO acceptance in Europe is suggested.

\subsubsection{Let consumer choose}

With some reservations it could be said that the divergence of the EU and the US policies in respect to the GM food products was caused, because the two have addressed the arrival of biotechnology from very different perspectives. In the light of novelty of the GMOs in food with its alleged dangers and unknown effects, several policy options were available. The first option roughly was a simple ban of use of GMOs in food products. The EC novel food policies before the WTO dispute was a better-hidden and more sophisticated form of such ban. ${ }^{126}$ The other extremity was the integration of conventional and biotech varieties into one production stream. This view was adopted in the US with their notion of substantial equivalency. It is quite obvious that these two extremes are not compatible and no supranational dispute settlement mechanism would be able to combine them. 
The only sustainable solution therefore would be a search for a middle way between the two extremes. As the underlying idea behind the restriction of the usage of the GMOs in food in Europe is the public or consumer refusal, let the consumer then indeed chose if he or she wants to buy and eat the GM food. The third way thus would be a creation of two production tracks and introduction of a labelling system to allow the consumer to identify the two varieties. ${ }^{127}$ Of course such suggestion implies that tracking and labelling of food products containing GMO are feasible. In practice, however, it will not be easy, bearing in mind that the only thing that in many cases differentiates a GM product from a non-GM product is a production method and not a detectable physical difference.

When two varieties of food products (containing GMO and GMO-free) are identified, then the real usage of the GM foods will depend on how consumers indeed accept them and how do they perceive danger and safety of such food. The perception by the consumers of GMOs and GM food products is, however, a tricky issue. Lately general hostility towards biotechnological applications in food products seems to be rather steady and rather insensitive to such incentives as price of a GM product. Yet what people say in surveys and what they would do in a super-market is not always the same.

The study, carried out in 2000 showed that far not every customer perceives the use of GM technology in food production to be a threat to food safety and of those who do, not all do so for the same reasons or to the same extent. ${ }^{128}$ Acceptance of GM food would increase, if consumers' perception of safety of GM food improved. In this regard, communication by policy-makers and other stakeholders is essential to address consumers' GM food safety concerns. The curious thing is that the mythically cautious and anti-GMO directed consumer indeed tends to behave differently in a particular situation when he/she faces 
the actual choice of buying a GM product, as another recently published experiment illustrated. ${ }^{129}$ The research not only questioned if the antiGMO sentiment expressed in surveys would be reflected in actual purchase behaviour, but also showed that hypothetical decisions (such as in surveys) of individuals may differ from a real commitment to purchase. ${ }^{130}$

Ironically, surveys show that individuals are willing to consume GM food but oppose to it in general. ${ }^{131}$ While surveys accompanied by media hysteria show, that the only appropriate policy satisfying the picky European consumer would be a total ban on GM foods, the described experiment, however, brings evidence that substantial part of the consumers would buy GM foods and accordingly receive a welfare gain (if the products are cheaper). On the basis of this data it could be suggested not to ban marketing the GM food and thus not to lose gains of trade. ${ }^{132}$ This recent data advocates segmenting the market into GMO-free products and products containing GMO. Hence, as long as the segregation costs are not greater than the welfare gains from the market segmentation it would be economically justified to establish two separate production tracks. ${ }^{133}$

Economically reasonable theoretic solution thus seems to be a system of labelling. ${ }^{134}$ Those numerous Europeans who remain sceptical of the benefits that genetic modification can deliver or who, for perceived quality reasons, prefer conventional or organic foods, would retain their unquestionable right to have access to the food they wish to consume, provided that authorisation mechanism functions properly and GMproducts that get to European market are indeed safe. ${ }^{135}$ However, there are several aspects capable of complicating the situation. Firstly, not all consumers buy food themselves and have a possibility to check what the particular food product contains (for example, people also eat in restaurants and other public places). Public caterers are entitled 
to receive information about the existence of the GMOs in food in the same manner as the final consumers, yet they are not under the obligation to provide such information further. ${ }^{136}$ Specific rules concerning information to be given by mass caterers providing food to the final consumer may be adopted through comitology procedure, but they are not yet. Secondly, the consumer choice makes sense only if the labelling is really accurate. The new legislation establishes a comprehensive labelling system for all food containing, consisting of or produced from a GMO. The presence of the GM material in conventional food does not have to be labelled only if it is below $0.9 \%$ and if it can be shown to be adventitious and technically unavoidable. Thus the threshold to treat food as conventional (or GMO-free) is set pretty low. Moreover, increasing demand for 'organic' or 'bio' food creates the demand for a $0 \%$ GMOs food. Hopefully a call for a lower threshold for 'organic' than for conventional product labelled as 'GMOfree' will not bring more confusion and will not end up with some products being described as 'GMO-free' and others described as 'more GMO-free'.

Therefore it could be said that the new EU regulatory framework (or at least the reasoning lying behind it) reflects a middle-way solution to the GMO dispute, if now also its proper implementation follows. Turning to the proposal to accept the GMOs under a strict condition of market segmentation and the way the EC copes with this proposal, it should be noted that it also will be measured by the WTO gauge. The major question here is whether the new system in the EC is compatible with the trade rules. Obviously it is 'more trade consistent' than the contested moratorium. As discussed in the preceding Chapter $\S 3.3$. on the TBT Agreement, the WTO approach to the mandatory labelling, as opposed to voluntary labelling schemes, is, however, somehow ambiguous. And the case law on interpretation of the TBT provisions is rather humble, leaving the Panel a lot of discretion and commentators a broad field for 
speculations. On the one hand allowing GMOs to the market under the strict labelling/traceability requirements is a large concession from the EC side, overstepping dislike of GMOs by the broader public. On the other hand it gives rise to fears that it would be an intermediary step to even more restrictions on 'green' biotechnology. ${ }^{137}$ In addition the GM exporters are equally unhappy about the labelling and traceability requirements as with the moratorium, since the enforcement of the new requirements involves the introduction of a costly crop identification and segregation. ${ }^{138}$

However, the only way to move away from the deadlock is if complainants in the dispute realise that labelling and traceability is the price to pay to end the moratorium. ${ }^{139}$ The most absurd, but still possible outcome of this bio-mess in the WTO would be if the panel/AB decided that the moratorium, since it has been lifted, was a 'provisional precautionary' measure, compatible with the SPS Agreement and then the US \& Co launched a new 'trade war' on the new regime of the EU in respect of labelling and traceability issues. ${ }^{140}$

\section{CONCLUSIONS}

The dispute over biotechnology products has thus started; and the Panel has a role to play now. However, a mere initiation of the dispute made the EU to move towards a more trade compatible GMO regulation. The initiation of the dispute has mobilised Commission to push forward the changes into the stalled European biotech sector. With the new regulatory framework it seeks to accomplish its vision of safe and beneficial usage of biotechnology, which among other issues also embraces admittance of GM foods (provided they are assessed to be safe) to the European markets. The declared goal to make European biotechnology sector more competitive perfectly suits to the surrealistic Lisbon agenda goals and serves as a ground for any supposedly 'effective' measure. While the Commission seems rather 
determined to push forward with the GMO approvals, the Member States use every possible loophole - as for example the adoption of very stringent provisions on liability - to reflect their more cautious policy towards the GMO. It seems that the fact that the Commission has acquired competences to deal with trade in GMO in the WTO, and to meet the consequent social, health and environmental problems therein, incites the Member States to partisan resistance in order to avoid submission to the disputable interest balance suggested by the WTO. The Commission thus finds itself facing both - the frustration of the trade partners and the opposition from the Member States in the GMO issues.

The double aim - to please both its Member States and its trade partners - hinders Commission's efforts to transform European GMO regulation to a more workable and trade compatible form. While the EU is obviously changing its approach to GMO approvals, almost any outcome of the dispute in the WTO (favouring either the complainants or the plaintiff) is possible. Moreover, the law governing the dispute allows for various interpretations and many of the facts of the case, especially the crucial one on the safety of the biotechnology, are ambiguous. Thus the decision, whatever it shall be, will be rather a political and not a legally unambiguous decision. The Panel has to choose between a condemnation of the EC, which will most likely lead to nonimplementation with consequential negative effects for the world trade system, and upsetting the complainants, which will in turn most probably result in the second dispute challenging the updated EU GMO regulatory framework.

Such never-ending litigation could be stopped only through a constructive dialogue, if both sides were willing to really find a solution to the multifaceted problem of the use of GMOs in food, or more generally about their broader uses and dangers. The GMO dispute is note a mere trade dispute, it is also a principal conflict that touches 
upon many non-economic values, and thus the dispute settlement in the WTO cannot cover all the relevant problems related to the resolution of this conflict. In this respect all the existing international fori could and should be employed.

Answering the question posed in the title - 'shall Europe further abstain from Frankenstein foods?' - it could be said that, to the regret of many, the EC cannot escape from the international obligations it has undertaken. The moratorium is over, and the GMOs will come to the European markets. Sooner or later they would have come in roundabout ways. Thus a strict system of market segmentation and labelling, which is provided for by the new EU GMOs regime, seems to be economically reasonable solution. However, such economically motivated solution does not solve the ethical dilemmas posed by GM-foods and does not indicate the point when the biotechnology should and must to stop reconfiguring the natural order. It will simply allow those many Europeans, who remain sceptical of the benefits of GM food and/or prefer conventional or organic foods, to access the food they wish to consume. This is feasible, however, only if one crucial condition is met - the authorisation mechanism functions properly delivering only indeed safe GM-products to European market. Moreover, it is desirable that new EU regime, if promptly implemented, will pass the WTO scrutiny. In addition it is even more desirable that it will function in the real world, providing that all GMOs that get to European markets can be labelled and indeed traced from 'farm to fork' so that European consumers can effectively execute their right of choice of food. (Provided that consumers read the labels and hopefully leave GM food in the shelves). 


\section{Notes}

${ }^{1}$ Presidency conclusions of Lisbon European Council 23 And 24 March 2000, can be found at: http://ue.eu.int/ueDocs/cms_Data/docs/pressData/en/ec/00100r1.en0.htm

${ }^{2}$ Verdurme A./ Viaene J. Consumer Perceptions of Food Safety: The Case of Genetically Modified Food. The IPTS (Institute for progressive technological studies) Report (65), 2002.

3 'Consumer preferences', which from the point of view of political economy are usually dispersed, are in the case of GMO's in Europe contrarily well mobilised and they make a stark opposition to introduction of GMO to European markets. According to the ETH study (T.Bernauer, E.Meins Technological revolution meets policy and the market: explaining cross-national differences in agricultural biotechnology regulation, European Journal of Political Research [2003], Vol. 42, No. 5, pp. 643$683)$, those preferences are better mobilised in Europe due to the role of anti-GMO nongovernmental organizations (NGOs), of an increased collective action capacity due to public outrage, of an institutional environment favourable to anti-biotechnology NGO interests (multilevel regulatory policy making) and of a disintegration of the producer coalition due to NGO campaigns and differences in industrial structure. These factors in turn reflect in the differences in biotechnology regulation across the ocean.

${ }^{4}$ Biotech - genetically modified organisms, a fact-sheet on EU external relations with US, can be found at: http://europa.eu.int/comm/external relations/us/sum06 03/ gmo.pdf

${ }^{5}$ Communication to the Commission For an orientation debate on Genetically Modified Organisms and related issues, published together with Press release IP/04/ 118GMOs: Commission takes stock of progress, Brussels, 28 Jan 2004, p.2.

${ }^{6}$ European Communities - Measures affecting the approval and marketing of biotech products, Request for consultations by the United States, 20 May 2003, WT/DS291/ 1.

7 Supra note 5, p.3.

${ }^{8}$ Supra note 4.

${ }^{9}$ Life Sciences and Biotechnology - a Strategy for Europe: $2^{\text {nd }}$ Progress Report and Future Orientations, a report from the Commission COM(2004)250 final, Brussels, 07 Apr 2004, p.21.

${ }^{10}$ European Communities - Measures affecting the approval and marketing of biotech products, Communication from the Chairman of the Panel to the DSB, 2 Nov. 2004, WT/DS291/27. 
${ }^{11}$ Commission authorises import of canned GM-sweet corn under new strict labelling conditions - consumers can choose, Press release IP/04/663 Brussels, 19 May 2004.

12 Syngenta does not market Bt-11 GE maize in the EU: Consumer resistance puts GM corn on hold, Press release of EurActiv 25 May 2004. Can be found at: http:// www.euractiv.com/cgi-bin/cgint.exe/1185812-30?1\&1000=1\&1011=index

${ }^{13}$ US to maintain challenge despite EU GM approval, Press release of Agra Europe 21 May 2004, document provided by HighBeam Research at: http:// www.highbeam.com

${ }^{14}$ Authorisation was issued on 19 May 2004, while 25 May 2004 was the last day for WTO members to put forward evidence in GMO case and the first hearing took place on 2 Jun 2004.

${ }^{15}$ GMOs: Commission authorises import of GM-maize for use in animal feed Press release IP/04/957, Brussels, 19 Jul 2004.

${ }^{16}$ It is not only the interim approach of the Commission, as reflected in Communication for an orientation debate on GMOs, supra, note 7, p.4, but also quite obvious national implementing measures.

17 G.Skogstad Legitimacy and/or policy effectiveness?: Network governance and GMO regulation in the European Union, Journal of European Public Policy 2003, Vol. 10, No.3, p.323.

${ }^{18}$ Council Directive 90/220/EEC of 23 April 1990 on the deliberate release into the environment of genetically modified organisms, [1990] OJ L 117, p.15.

${ }^{19}$ Directive 2001/18/EC of the European Parliament and Council of 12 March 2001 on the deliberate release of genetically modified organisms, [2001] OJ L 106, p.1.

${ }^{20}$ Being called 'one of the most powerful weapons in the environmental arsenal (T.J.Daemen The European Community's evolving precautionary principle : comparisons with the United States and ramifications for Doha round trade negotiations, European Environmental Law Review 2003, Vol.12, No.1, p.6), the precautionary principle was first granted a treaty-level reference in the Maastricht Treaty, though Community support for it dates much earlier. Development of Community soft law as well as case-law of the ECJ/CFI on the precautionary principle are covered in Chapter $\S$ 3.2.3. in greater detail.

${ }^{21}$ Regulation (EC) No 1829/2003 of the European Parliament and of the Council of 22 September 2003 on genetically modified food and feed, [2003] OJ L 268, p. 1, Regulation (EC) No 1830/2003 of the European Parliament and of the Council of 22 September 2003 concerning the traceability and labelling of genetically modified organisms and the traceability of food and feed products produced from genetically modified organisms and amending Directive 2001/18/EC, [2003] OJ L 268, p. 24.

22 Ibid., Labelling/traceability Regulation Art. 4(4). 
${ }^{23}$ Italy, principally opposing to then still possible 'simplified' authorisation procedure, suspended 'temporally' the use of seven GM food products under Novel Food regulation, while other nine national safeguard clauses were invoked under environmental legislation (in Austria, France, Germany, Luxembourg, Greece and UK).

${ }^{24}$ Supra note 5, p.2.

${ }^{25}$ Case 236/01 Monsanto Agricoltura Italia SpA and Others v Presidenza del Consiglio dei Ministri and Others, Judgment of the Court of 9 September 2003, [2003] ECR I08105.

${ }^{26}$ E.Thijs, H.Somsen Case C-236/01: Monsanto Agricoltura Italia SpA and others v. Presidenza del Consiglio dei Ministeri and others, European Environmental Law Review 2004, Vol. 13, No. 1, pp.16-17.

${ }^{27}$ Also in the latest Internal market Scoreboard this directive is still among the 'champions' of being not implemented, Internal Market Scoreboard 2004: details of transposition, 13/07/2004, Reference: MEMO/04/176.

28 There are eight pending cases on the issue: cases C-416/03 to C-424/03, case notes OJ 2003 C 275/60, p.39 to OJ 2003 C 275/68 p.42. See also, supra, note 9 , p.19.

${ }^{29}$ Supra, note 17, p.323.

${ }^{30}$ According to Skogstad, supra, note 17, p.336, Commission services responsible for Trade, Industry, Competition, and Research had quite opposite approaches to the ones of Environment and SANCO (Health and Consumer Protection).

${ }^{31}$ As recent researches demonstrate, also the 'cautious Europeans' maybe are not that hostile towards GMO foods, see infra, Chapter $\S$ 4.3.1. See also Ch.Noussair, St.Robin, B.Ruffieux Do consumers really refuse to buy genetically modified food? The Economic Journal 2004, Vol. 114, No. 492, pp. 102-120.

${ }^{32} \mathrm{~A}$ good example could be Syngenta's (the one that could have enjoyed 'historical' first authorisation) immediate announcement that it will not commercialise the approved product for the time being due to strong consumer resistance. As a reason for this, Syngenta referred to the resistance of the European food industry to add GM corn to their product range, Consumer resistance puts GM corn on hold, 25 May 2004, Press release: EurActiv, GENET-news, http://www.euractiv.com/cgi-bin/cgint.exe/ $1185812-30 ? 1 \& 1000=1 \& 1011=$ index

${ }^{33}$ Although Directive 2004/35/CE on environmental liability with regard to the prevention and remedying of environmental damage (see, [2004] OJ L 143, p.56) foresees a wide range of environmental liability grounds, it excludes liability were a permit or authorisation has been issued for the operator by authorities. This exception would be clearly applicable to the GMOs authorisations issued under Directive 2001/18/ $E C$, thus waiving liability for the release. In this sense the Liability Directive is quite 
limited and is unlikely to have significant effect on damages resulting from GMOs issues. Respectively, the issues of liability related to the damage caused by GMOs are left to regulate by the civil laws of the Members States, while the decision, which could cause a potential damage (i.e. the authorisation to release a GMO to the market) is taken purely at the Community level. While liability issues related to the releases of GMO currently are not covered under the EC law, national law prescribes conditions of liability in such way, that farmers could be advised against growing GM crops at all. A good example for this could be a draft German 'Gentech' law, which at the time of writing was approved by German Parliament (BT) and was pending before the Government. First, conventional farmers are entitled to file for hefty damages (See, Part V of the draft law) in case of contamination of their crops, secondly farmers opting for GMO crops are to register with a national database and in case they violate farming regulations they are subjected for hefty fines or even imprisonment up to five years. See Gesetzesentwurf zur Neuordnung des Gentechnikrechts, found at: http://dip.bundestag.de/btd/15 /030/1503088.pdf

34 The same Syngenta not only announced that it will not market the approved maize, but more recently also that it would move its commercial research into GM crops from the UK, because of 'the poor business outlook for the technology', to the US. Syngenta to end GM tests in UK Financial Times, 1 Jul 2004, p.1.

${ }^{35}$ Supra, note 6.

${ }^{36}$ For the 'defending opinion' see for example, S.Lively The ABCs And NTBs Of GMO's The great European Union-United States Trade Debate-Do European Restrictions on the Trade of Genetically Modified Organisms Violate International Trade Law? Northwestern Journal of International Law \& Business [2002], Vol.23, No.1, p. 239261 , and the 'convicting response' to it by J.S.A.Claus The European Union's efforts to sidestep the WTO through its ban on GMOs: a response to Sarah Lively's paper, "The ABCs and NTBs of GMOs", Northwestern Journal of International Law \& Business [2003], Vol.24, No.1, p. 173-198.

${ }^{37}$ As enshrined in the preamble to Marrakesh agreement. Agreement establishing the World Trade Organization, 15 Apr. 1994.

${ }^{38}$ As named by the Appellate Body in Report on Shrimp and Sea Turtles (US - Import prohibition of shrimp and shrimp products, Report of the Appellate Body, 12 Oct.1998 WT/DS58/AB/R), para. 152.

39 Ibid.

${ }^{40}$ „[A] balance must be struck between theright of a Member to invoke an exception under Article XX and the duty of that same Member to respect the treaty rights of the other Members". Ibid., para. 156.

${ }^{41}$ The preamble of the TBT Agreement seeks „to ensure that technical regulations and standards... do not create unnecessary obstacles to international trade,,, while the 
preamble of the SPS Agreement aims at "the establishment of a multilateral framework ... in order to minimize their [of sanitary and phytosanitary measures] negative effects on trade,.. See, Agreement on Technical Barriers to Trade, and Agreement on the Application of Sanitary and Phytosanitary Measures, both signed on 15 Dec. 1993.

${ }^{42}$ EC treaty, e.g. Articles 3 and 95, see Consolidated version of the Treaty establishing European Community [2002] OJ C 325, p.33.

${ }^{43}$ General Agreement on Tariffs and Trade, 30 Oct. 1947.

44 Ibid., Annex I, Notes and supplementary provisions ad Article III.

45 St.Woolcock The Precautionary Principle in the EU and Its Impact on International Trade Relations CEPS Working Documents, No. 186, October 2002, p. 27.

46 US - Restrictions on Imports of Tuna, GATT Panel Report, BISD 39S/155, paras. 5.14-5.15.

47 Supra, note 38.

${ }^{48}$ These four criteria being, as lately again confirmed in Asbestos dispute,: 1. Properties, nature and quality of the products; 2 . End-uses of the products; 3 . Consumers' tastes and habits; and 4. The tariff classification of the products. EC-Measures Affecting Asbestos and Asbestos-Containing Products, Appellate Body Report, 12 Mar. 2001, WT/DS135/AB/R, para. 101.

49 J. Wong Are Biotech Crops And Conventional Crops Like Products? An Analysis Under GATT Duke Law \& Technology Review, 2003 Oct, Vol.27, p. 27-28.

50 Supra, note 26, p.4.

${ }^{51}$ Supra, note 25, para.74.

${ }^{52}$ Chaepau of Art. XX GATT, see supra, note 43.

${ }^{53}$ Agreement on Technical Barriers to Trade and Agreement on the Application of Sanitary and Phytosanitary Measures both signed on 15 Dec. 1993.

${ }^{54}$ Whether measures on GMOs are covered by the SPS at all is highly contentious and has been widely discussed, see, for example, Th.Spanggaard The marketing of GMOs: a supra-national battle over science and precaution Yearbook of European environmental law [2003], Vol. 3, p.98.

${ }^{55}$ SPS measure is defined in Art.1 of the Annex A, where also a non-exhaustive list of SPS measures is provided.

${ }^{56}$ P.Vergano The Sanitary and Phytosanitary Agreement, in ERA-Forum: Scripta luris Europaei, 2001, No.4, p.118.

${ }^{57}$ G.E.Isaac, W.A.Kerr Genetically modified organisms at the World Trade Organization : a harvest of trouble, Journal of World Trade [2003], Vol. 37, No. 6, p.1092.

${ }^{58}$ Art. 2(2) SPS, see supra, note 53.

${ }^{59}$ According to Appellate Body Report in Beef Hormones, measures adopted pursuant to Art. 3(3) SPS must conform to basic obligations of Art.2 SPS and requirements of 
Art.5 SPS. EC - Measures Concerning Meat and Meat Products (Hormones) Appellate Body Report, 16 Jan. 1998, WT/DS26/R/USA, WT/DS48/AB/R., para. 176. ${ }^{60}$ Art. 5 SPS, see supra, note 53.

${ }^{61}$ So far only Draft Principles for the Risk Analysis of Foods Derived from Modern Biotechnology CAC/GL 44-2003 and guidelines on safety assessment were adopted on 7 July 2003. The labelling issues still remain under the discussion. Bearing in mind rather diverging positions of the included actors it is not likely that any agreement would be achieved soon, if at all.

62 See for example, Codex Alimentarius Guidelines for the Conduct of Food Safety Assessment of Foods Produced Using Recombinant-DNA Microorganisms CAC/ GL 46-2003, at point 5.

${ }^{63}$ Art 5.2. SPS (supra, note 53) provides such list to be considered in risk assessment: available scientific evidence; processes and production methods; inspection, sampling and testing methods; prevalence of specific diseases or pests; existence of pest- or disease-free areas; relevant ecological and environmental conditions; and quarantine or other treatment.

${ }^{64}$ Supra, note 56, p.121.

${ }^{65}$ Beef Hormones para.187, see supra, note 59.

${ }^{66}$ Supra, note 56, p.122,

${ }^{67}$ Beef Hormones para.193, see supra, note 59,.

${ }^{68}$ Supra, note 36, Claus, J.S.A., p.189.

${ }^{69}$ In relation to the scientific information the Panel acknowledged already in Asbestos case that it is not its function to settle a scientific debate, as it is not composed of experts in the field. Panel would limit itself just to determine whether there is sufficient scientific evidence to conclude that there exists a risk for human life or health and that the measures taken by a Member are necessary in relation to the objectives pursued. EC-Measures Affecting Asbestos and Asbestos-Containing Products, Panel Report, 18 Sep. 2000, WT/DS135/R, paras.8.181-8.182. However, in case of GMOs the Panel will engage in deciding on the 'insufficiency of evidence', which in itself is a 'scientific debate'.

70 Japan - Measures Affecting Imports of Apples, Appellate Body Report, 26 Nov. 2003, WT/DS245/AB/R, para.184.

${ }^{71}$ Supra, note 54, p.108.

72 Supra, note 45, p.7.

${ }^{73}$ Ibid.

${ }^{74}$ Supra, note 3, p.645.

${ }^{75}$ First, the focus of the US lies exclusively on the end product of GM technology, rather than on the fact that the process of genetic modification is used. Second, it presumes low risk from genetic modification and therefore holds that in the absence of verifiable 
'scientific risk' there is no reason to bar a use of technology. Finally, it maintains that any risks of GM foods are of the same kind as those of "traditionally" produced foods and therefore they are sufficiently assessed with existing regulatory oversight, for more see: E.Marden Risk and Regulation: U.S. Regulatory Policy on Genetically Modified Food and Agriculture, Boston College Law Review, 2003, Vol. 44, p.734.

${ }^{76}$ See K.-H. Ladeur The introduction of the precautionary principle into EU law : a pyrrhic victory for environmental and public health law? Decision-making under conditions of complexity in multi-level political systems, Common Market Law Review 2003, Vol.40, No.6, p.1458ff.

77 See, for example 'Science v. Precaution' by Th.Spanggaard (supra, note 54), or J.S.A.Claus (supra, note 36 ).

${ }^{78}$ The difference is that in conventional risk assessment those not purely scientific considerations are frequently denied and concealed, whilst in the case of precaution they are more readily acknowledged and explicit, according to P.van Zwanenberg, A.Stirling Risk and precaution in the US and Europe: a response to Vogel, Yearbook of European environmental law 2003, Vol.3, p.47.

79 Ibid., p.55.

${ }^{80}$ Supra, note 20, p.6.

${ }^{81}$ Communication from the Commission on the precautionary principle $\operatorname{COM}(2000) 1$, Brussels, 2 Feb 2000 pp.10-12.

82 Ibid., p.4.

${ }^{83}$ As is demonstrated, for example, by national safeguard-clauses cases (i.e. already cited Monsanto case (footnote 25)). See also G. Majone What price safety?: the precautionary principle and its policy implications, Journal of Common Market Studies 2002, Vol. 40, No. 1, p.107.

84 „Judicial review of the observance of the precautionary principle must be exercised with caution“, Case C-241/01, National Farmers' Union v Secrétariat général du gouvernement, Opinion of AG Mischo 2 Jul 2002, [2002] ECRI-9079, para 73.

${ }^{85} \mathrm{Cf}$. Case T-13/99 Pfizer Animal Health SA v Council of the European Union, Judgment of CFI 11 Sep 2002, [2002] ECR II-3305. 'The protection of public health [...] must take precedence over economic considerations', paras. 456, 471.

${ }^{86} \mathrm{~W}$. Th. Douma, Fleshing out the precautionary principle by the Court of First Instance : Pfizer Animal Health SA v Council of the European Union, Journal of Environmental Law 2003, Vol.15, No.3, p.405.

${ }^{87}$ Cf. Reasoning on application of precautionary measures in Judgement of Monsanto case (supra, note 25). See in particular paras. 106-114.

${ }^{88}$ Supra, note 57, p.1088.

89 Supra, note 54, p.123. 
${ }^{90}$ EC-Measures Concerning Meat and Meat Products (Hormones) Panel Report, 18 Aug. 1997, WT/DS26/R/USA, para.1578.

${ }^{91}$ Beef Hormones paras. 8.157 - 8.158, see supra, note 65.

${ }_{92}$ Following the terminology used by T. Spanggaard (see supra, note 54).

${ }^{93}$ Despite the resistance from the so-called 'Miami group countries', i.e. GM crops exporting countries, the Cartagena Protocol provides for the application of the precautionary principle for LMO (live modified organisms). A rigorous procedure of advanced informed agreement (AIA) applies to the first intentional transboundary movement of LMOs for intentional introduction into the environment by the party of import. However, in case of LMOs in food products, the precaution is more limited: the AIA does not apply, as LMOs in food are supposed not to threat to the environment. Cartagena Protocol On Biosafety to the convention on biological diversity, adopted 29 Jan 2000, in force since 11 Sep 2003.

${ }^{94}$ D. Brack, R. Falkner, J. Goll The Next Trade War? GM Products, the Cartagena Protocol and the WTO. 2003 Briefing Paper No.8, The Royal Institute of International Affairs, p.4.

${ }^{95} \mathrm{C}$. Hutchison International environmental law attempts to be "mutually supportive“ with international trade law: a compatibility analysis of the Cartagena Protocol to the Convention on Biological Diversity with the World Trade Organisation agreement on the application of sanitary and phytosanitary measures. Journal of International Wildlife Law \& Policy 2001 Vol.4, No.1, p. 32.

${ }^{96}$ Normally Article 30(3) of the Vienna Convention on the Law of Treaties ([1969] 1155 UNTS 331) would provide, that where two treaties address the same subject matter, the later treaty shall prevail (in case of GMOs that means - the Cartagena Protocol). However, this does not apply to a non-party to the later treaty (i.e. under general rule of Vienna Convention Cartagena Protocol does not prevail in the relations of the EU with the complainants in the GMO dispute).

${ }^{97}$ Supra, note 38. See also, R. Eckersley The Big Chill: The WTO and Multilateral Environmental Agreements Global Environmental Politics, May, 2004, p.24.

${ }_{98}$ Both Thuna Dolphin and Shrimp Turtle, were lost by the U.S, limiting the scope of their environmental regulations.

${ }^{99}$ A highly conspicuous feature of the Convention on Biological Diversity and its Cartagena Biosafety Protocol, as of many other significant MEAs (such as the Basel Convention and the Kyoto Protocol) is the lack of US support to them. Rather the constant dissent of the US may be observed.

100 Supra, note 97.

${ }^{101}$ Art 1.5 TBT, see supra, note 53.

102 There is also a contrary view, arguing that the segregation of GM-products/crops from their non-GM counterparts, required by the EU legislation and not required by 
the U.S. in fact is a trade barrier that falls nevertheless under TBT. See, supra, note 57, p.1093.

${ }^{103}$ Committee on Trade and Environment, Report to the 5

th Session of the WTO Ministerial Conference in Cancún WT/CTE/8, 11 Jul 2003.

104 In certain food (e.g. highly processed food products) existence of GM products cannot be detected. Traceability therefore is the only way to prove and track existence of the GMO in food.

${ }^{105}$ See proposed Codex Alimentarius Draft Guidelines for the labelling of food and food ingredients obtained through certain techniques of Genetic Modification/Genetic Engineering, Alinorm 04/27/22, Appendix Vi, Art.6.0. See also paras 79-94 of considerations by the participating delegations (particularly paras 80-81 - U.S. and EC positions).

106 See Codex Alimentarius Principles for the Risk Analysis of foods derived from Modern Biotechnology Foods, CAC/GL 44-2003, paras. 19-21.

${ }_{107}$ Only the products were GM material is bellow the set threshold $(0,9 \%)$ are excluded from the labelling/traceability obligation, if it can be shown to be adventitious and technically unavoidable.

${ }^{108}$ Articles 2.2, 2.10, 5.4., 5.7 TBT, see supra, note 53. See also M. Gruber Inside or outside?: The role of the WTO in the settlement of the transatlantic trade dispute on GMOs, Intereconomics 2004, Vol.39, No.1, p.40.

109 R. Mackenzie The international regulation of modern biotechnology Yearbook of International Environmental Law 2002, Vol.13, pp.130-131.

110 Ibid., p.160.

111 Supra, note 114, pp.42-43.

112 Ibid., p.40.

113 The fact that European investment in plant genomics and biotechnology has stalled in recent years is attributed at least partly to a stringent regulation and its inconsistent implementation. Moreover, European biotech firms are increasingly turning to nonEU customers and relocating their research activities and investments to US, China, Japan and even India and Argentina. It seems that Europe risks losing out on its investment in plant genomics and biotechnology as the exploitation of its science and technology base will increasingly be done outside the EU, where global use of these plants is on the rise, with $99.5 \%$ grown in the meantime. The Vision Paper: „2025: a European vision for plant genomics and biotechnology“ IP/04/801 Brussels, 24 Jun 2004, p.13.

114 Supra, note 108, p.41.

${ }^{115}$ As Art. 5 of the DSU provides for, 'good offices, conciliation or mediation may begin and be terminated at any time', Understanding on Rules and Procedures Governing the Settlement of Disputes, Annex II to Agreement Establishing the WTO. 
116 The Commission continuously asserts that initiation of dispute is ad odds with 'spirit of co-operation' for modern technology regulation and, in its own words, „the Commission views the WTO challenge on GMOs as an obstacle to the search for common, trade-enhancing approaches to biotechnology", see supra, note 9, p.21.

117 Supra, note 57, p.1085.

118 Ibid.

${ }^{119}$ See, EC - Measures Concerning Meat And Meat Products (Hormones), Request for Arbitration by the European Communities, 16 Apr 1998, WT/DS26/14, WT/DS48/ $12, \mathrm{G} / \mathrm{L} / 235$.

120 See, EC - Measures Concerning Meat And Meat Products (Hormones), Communication from the European Communities, 28 Oct 2003, WT/DS26/22, WT/ DS48/20.

${ }^{121}$ See, Directive 2003/74/EC of European Parliament and Council of 22 September 2003 amending Council Directive 96/22/EC Concerning the prohibition on the use in stockfarming of certain substances having a hormonal or thyrostatic action and of Beta-agonists, [2003] OJ L 262, p.17.

${ }^{122} \mathrm{D}$. Wüger The never ending story: the implementation phase in the dispute between the EC and the United States on hormone-treated beef , Law and Policy in International Business 2002, Vol.33, No.4, p.798.

${ }^{123}$ Which was not actually implemented, ibid., p.804 ff.

${ }^{124}$ Supra, note 57, p.1094.

${ }^{125}$ Moreover, it is not accurate to claim that only the US and the WTO had suffered because non-implementation of Beef Hormones decision by the EU. Within the EU economic operators, which were actually touched by the import bans, were claiming damages for their infringed rights under Beef Hormones in the Community courts, e.g. Biret cases, in which the key issue were if a private party might claim damages from EU for failure to implement the WTO ruling (Judgements of 30 September 2003 in Case C-93/02 P, Biret International v Council and Case C- 94/02 P Etablissements Biret \& Cie SA v Council [2003] ECR I-10497).

${ }^{126}$ However, it should be noted that it is impossible to absolutely prevent European markets from GM products: although unauthorised they nevertheless come in indirect ways (and remain untraced and unlabelled). A good example would be an uncontrolled GMO spreading through some candidate countries, which willingly cultivate and seek to export GM crops (e.g. Romania is Europe's sole producer of GM soyabean with about 35,00 hectares under cultivation, see, Radu Marinas Romanians say GM soya beats smelly salami Press Release, Reuters, 04 Jun 2004. Could be fount at: http://www.agbioworld.org/newsletter wm/ index.php?caseid=archive\&newsid=2127). As the regime for goods from a candidate country to the EC reflects something between common market and FTA, 
biotech companies try to find a bypass to the European markets in this way. Of course GMOs would not spread across borders if the EC rules on traceability and labelling were effectively observed in candidate countries. Hopefully they, seeking a real accession will be compelled to implement properly the EC aquis on GMOs.

${ }^{127}$ Supra, note 31, p. 117.

${ }^{128}$ Supra, note 2.

${ }^{129}$ Supra, note 31.

$130 \mathrm{Ibid} .$, p.103. It could be also so if, for example, GMOs would viewed as carrying an environmental risk but also as safe for human.

$131 \mathrm{lbid}$. The two different thresholds, $0.1 \%$ and $1 \%$, were clearly perceived as meaningfully different. Furthermore, the research showed that demand of a product is decreasing, when GMO content is higher. $89 \%$ of participants were willing to purchase a product satisfying the $1 \%$ threshold (the maximum content that the EU exempts from labelling is $0,9 \%$ ). Lowering the threshold to $0.1 \%$ would make even $96 \%$ of participants willing to purchase products satisfying the threshold, if they were sufficiently inexpensive.

132 Ibid., p.117.

133 Ibid.

${ }^{134}$ On the contrary, the ethical dilemmas of GM-foods are harder to pin down and resolve. Such economical solution does not show when the biotechnology should and ought to stop reconfiguring the natural order, see supra, note 113, p.12.

135 Mandatory labelling is a solution to cope with information asymmetry for consumer, but not for health concerns, in other words it is to protect 'right to know'. Thus its prerequisite is that the products on the market are safe. For a rather discouraging data, that GM products can hardly be proved to be safe, because of substantial scientific uncertainty, refer to Amicus Curiae Brief, submitted in the beginning of June 2004 to the Panel dealing with GMO dispute, found at: http://www.ciel.org/ Publications/ECBiotech AmicusBrief 2June04.pdf.

${ }^{136}$ GM Food Regulation Art. 12(1) and Art. 14(2), see supra, note 21.

${ }^{137}$ Supra, note 3, p.662.

${ }^{138}$ Same requirements affect also European biotechnology firms, who have opposed total GMO labelling because of worries about its negative commercial effects. For example, European Bioindustries Association advocated against 'discriminatory or misleading' mandatory labelling in the case of highly refined foods and feeds, where the genetic modification cannot be detected or verified. It supported labelling only, when it would be demonstrated that GM product differs from that of the conventional counterparts (See, EuropaBio Comments on Alinorm 03/22 Appendix III/IV, http://www.europabio.org/pages/workgroups detail.asp?wo id=12 done at Brussels, 14 Apr 2003) 
139 Certain Commission services were first to experience such unpleasant change and were made to accept a stringent labelling regulatory approach, as a condition to the admittance of the GMOs (supra, note 17, p.331).

${ }^{140}$ Supra, note 94, p.8. 


\section{BASLER SCHRIFTENZUR EUROPÄISCHEN INTEGRATION}

O Wir bestellen die Schriftenreihe im Jahresabonnement zu CHF 120.-. Das Abonnement verlängert sich automatisch um ein Jahr, wenn es nicht drei Monate vor Ablauf schriftlich gekündigt wird.

O Wir bestellen folgende Nummern zum Preis von CHF 20.- (Doppelnr 30.-)

$O$ Wir sind an einem Publikationsaustausch interessiert.

O Wir sind an Weiterbildungs-Unterlagen (Nachdiplomkurs) interessiert.

* vergriffen

O Nr. 1 Subsidiarität - Schlagwort oder Kurskorrektur (mit Beiträgen von Flavio Cotti, Jean-Paul Heider, Jakob Kellenberger und Erwin Teufel) (Doppelnummer) $)^{*}$

O Nr. 2 Ein schweizerisches Börsengesetz im europäischen Kontext (Tagungsband/Doppelnummer) ${ }^{*}$

O Nr. 3 Martin Holland, The European Union's Common Foreign and Security Policy: The Joint Action Toward South Africa*

O Nr. 4 Brigid Gavin, The Implications of the Uruguay Round for the Common Agricultural Policy

O Nr. 6 Urs Saxer, Die Zukunft des Nationalstaates

O Nr. 7 Frank Emmert, Lange Stange im Nebel oder neue Strategie? Die aktuelle Rechtsprechung des EuGH zur Warenverkehrsfreiheit

O Nr. 8 Stephan Kux, Subsidiarity and the Environment: Implementing International Agreements

O Nr. 9 Arbeitslosigkeit (mit Beiträgen von Christopher Boyd, Wolfgang Franz und Jean-Luc Nordmann)

O Nr.10 Peter Schmidt, Die aussenpolitische Rolle Deutschlands im neuen Europa

O Nr.11 Hans Baumann, Möglichkeiten und Grenzen der Sozialen Di-mension nach Maastricht: Das Beispiel der Bauwirtschaft *

O Nr.12 Georg Kreis, Das schweizerische Staatsvertragsreferendum: Wechsel-spiel zwischen indirekter und direkter Demokratie

O Nr.13 Markus Lusser, Die europäische Währungsintegration und die Schweiz 
O Nr.14 Claus Leggewie, Ist kulturelle Koexistenz lernbar?

O Nr.15 Rolf Lüpke, Die Durchsetzung strengerer einzelstaatlicher Umweltschutznormen im Gemeinschaftsrecht (Doppelnummer)

O Nr.16 Stephan Kux, Ursachen und Lösungsansätze des Balkankonflikts: Folgerungen für das Abkommen von Dayton

O Nr.17 Jan Dietze/Dominik Schnichels, Die aktuelle Rechtssprechung des Europäischen Gerichtshofes zum Europäischen Gerichtsstands- und Vollstreckungsübereinkommen (EuGVÜ)

O Nr.18 Basler Thesen für die künftige Verfassung Europas (2. Aufl.)

O Nr.19 Christian Garbe, Subsidiarity and European Environmental Policy: An Economic Perspective

O Nr.20 Claudia Weiss, Die Schweiz und die Europäische Menschenrechtskonvention: Die Haltung des Parlaments 1969-1995

O Nr.21 Gunther Teubner, Globale Bukowina: Zur Emergenz eines transnationalen Rechtspluralismus

O Nr.22 Jürgen Mittelstrass, Stichwort Interdisziplinarität (mit einem anschliessenden Werkstattgespräch)

O Nr.23 William James Adams, The Political Economy of French Agriculture

O Nr.24 Aktuelle Fragen der Wirtschafts- und Währungsunion (mit Beiträgen von Gunter Baer, Peter Bofinger, Renate Ohr und Georg Rich) (Tagungsband/Doppelnummer)

O Nr.25 Franz Blankart, Handel und Menschenrechte

O Nr.26 Manfred Dammeyer/Christoph Koellreuter, Die Globalisierung der Wirtschaft als Herausforderung an die Regionen Europas

O Nr.27 Beat Sitter-Liver, Von Macht und Verantwortung in der Wissenschaft

O Nr.28 Hartwig Isernhagen, Interdisziplinarität und die gesellschaftliche Rolle der Geistes- und Kulturwissenschaften

O Nr.29 Muriel Peneveyre, La réglementation prudentielle des banques dans I'Union Européenne

O Nr.30 Giuseppe Callovi/Roland Schärer/Georg Kreis, Citoyenneté et naturalisations en Europe

O Nr.31 Peter Häberle, Gemeineuropäisches Verfassungsrecht

O Nr.32 Jacques Pelkmans, Europe's Rediscovery of Asia. Political, economic and institutional aspects 
O Nr.34 Valéry Giscard d'Estaing, L’Union Européenne: Elargissement ou approfondissement?

O Nr.35 Martin Holland, Do Acronyms Matter? The Future of ACP-EU Relations and the Developing World

O Nr.36 Andreas Guski, Westeuropa - Osteuropa: Aspekte einer problematischen Nachbarschaft

O Nr.37 Matthias Amgwerd, Autonomer Nachvollzug von EU-Recht durch die Schweiz - unter spezieller Berücksichtigung des Kartellrechts (Doppelnr.)

O Nr.38 Manfred Rist, Infotainment oder Sachinformation? Die Europäische Union als journalistische Herausforderung (Doppelnummer)

O Nr.39 Lothar Kettenacker/Hansgerd Schulte/Christoph Weckerle, Kulturpräsenz im Ausland. Deutschland, Frankreich, Schweiz

O Nr.40 Georg Kreis/Andreas Auer /Christoph Koellreuter, Die Zukunft der Schweiz in Europa? Schweizerische Informationstagung vom 15. April 1999 veranstaltet durch das EUROPA FORUM LUZERN

O Nr.41 Charles Liebherr, Regulierung der audiovisuellen Industrie in der Europäischen Union

O Nr.42/3 Urs Saxer, Kosovo und das Völkerrecht. Ein Konfliktmanagement im Spannungsfeld von Menschenrechten, kollektiver Sicherheit und Unilateralismus

O Nr.44/5 Gabriela Arnold, sollen Parallelimporte von Arzneimitteln zugelassen werden? Eine Analyse der Situation in der Europäischen Union mit Folgerungen für die Schweiz

O Nr.46 Markus Freitag, Die politischen Rahmenbedingungen des Euro: Glaubwürdige Weichenstellungen oder Gefahr möglicher Entgleisungen?

O Nr.47/8 Andrew Watt, „What has Become of Employment Policy?“ - Explaning the Ineffectiveness of Employment Policy in the European Union

O Nr.49 Christian Busse, Österreich contra Europäische Union - Eine rechtliche Beurteilung der Reaktionen der EU und ihrer Mitgliedstaaten auf die Regierungsbeteiligung der FPÖ in Österreich

O Nr.50 Thomas Gisselbrecht, Besteuerung von Zinserträgen in der Europäischen Union - Abschied vom Schweizerischen Bankgeheimnis? 
O Nr.51 Uta Hühn, Die Waffen der Frauen: Der Fall Kreil - erneuter Anlass zum Konflikt zwischen europäischer und deutscher Gerichtsbarkeit? EuGH, Urteil vom 11.1.2000 in der Rs. C-283/98, Tanja Kreil/BRD

O Nr.52/3 Thomas Oberer, Die innenpolitische Genehmigung der bilateralen Verträge Schweiz - EU: Wende oder Ausnahme bei aussenpolitischen Vorlagen?

O Nr.54 Georg Kreis, Gibraltar: ein Teil Europas - Imperiale oder nationale Besitzansprüche und evolutive Streiterledigung.

O Nr.55 Beat Kappeler, Europäische Staatlichkeit und das stumme Unbehagen in der Schweiz. Mit Kommentaren von Laurent Goetschel und Rolf Weder.

O Nr.56 Gürsel Demirok, How could the relations between Turkey and the European Union be improved?

O Nr.57 Magdalena Bernath, Die Europäische Politische Gemeinschaft. Ein erster Versuch für eine gemeinsame europäische Aussenpolitik

O Nr.58 Lars Knuchel, Mittlerin und manches mehr. Die Rolle der Europäischen Kommission bei den Beitrittsverhandlungen zur Osterweiterung der Europäischen Union. Eine Zwischenbilanz

O Nr.59 Perspektiven auf Europa. Mit Beiträgen von Hartwig Isernhagen und Annemarie Pieper

O Nr.60 Die Bedeutung einer lingua franca für Europa. Mit Beiträgen von Georges Lüdi und Anne Theme

O Nr.61 Felix Dinger, What shall we do with the drunken sailor? EC Competition Law and Maritime Transport

O Nr.62 Georg F. Krayer, Spielraum für Bankegoismen in der EU-Bankenordnung

O Nr.63 Philippe Nell, China's Accession to the WTO: Challenges ahead

O Nr.64 Andreas R. Ziegler, Wechselwirkung zwischen Bilateralismus und Multilateralismus Das Beispiel der Freihandelsabkommen der EFTAStaaten

O Nr.65 Markus M. Haefliger, Die europäische Konfliktintervention im burundischen Bürgerkrieg, („Arusha-Prozess“)von 1996 bis 2002 
O Nr.66 Georg Kreis (Hrsg), Orlando Budelacci (Redaktion): Der Beitrag der Wissenschaften zur künftigen Verfassung der EU. Interdisziplinäres Verfassungssymposium anlässlich des 10 Jahre Jubiläums des Europainstituts der Universität Basel.

O Nr.67 Francis Cheneval, Die Europäische Union und das Problem der demokratischen Repräsentation.

O Nr.68 Politik und Religion in Europa. Mit Beiträgen von Orlando Budelacci und Gabriel N. Toggenburg.

O Nr.69 Chantal Delli, Das Wesen der Unionsbürgerschaft, Überlegungen anhand des Falls Rudy Grzelczyk gegen Centre public d'aide sociale d'Ottignies-Louvain-la-Neuve.

O Nr.70 Federica Sanna, La garantie du droit de grève en Suisse et dans la L'Union européenne.

Europainstitut der Universität Basel, Gellertstrasse 27, CH-4020 Basel, Schweiz, Tel. ++41 (0) 613179767 , FAX ++41 (0) 613179766

E-mail: europa@unibas.ch, Internet: www.europa.unibas.ch

C Europainstitut der Universität Basel 2004

Alle Rechte vorbehalten. Nachdruck, auch auszugsweise, sowie die Verbreitung auf elektronischem, photomechanischem oder sonstigem Wege bedürfen einer schriftlichen Genehmigung des Europainstituts. 